\title{
IDENTIFICATION OF DROUGHT TOLERANT MOLECULAR MARKERS IN RICE (Oryza sativa L.) \\ I- ASSESSMENT OF F1 GENOTYPES UNDER NORMAL AND DROUGHT CONDITION
}

El Banna, M. N.* ; H. M. F. El-Wakil ; A. A. Abd-Allah ${ }^{\star *}$; Hala F. Eissa***; S. E. Hassanein ${ }^{\star \star \star}$ and R. A. Sllam ${ }^{\star *}$

* Fac. of Agric. Saba Basha, Alex University,

** Rice Res. and Training Center, Field Crop Research Institute, (ARC),

${ }^{\star \star \star}$ Agriculture Genetic Engineering Research Institute, (ARC).

\begin{abstract}
The present study was carried out at the Experimental Farm of the Rice Research and Training Center (RRTC), Sakha, Kafer EL-Shiekh, Egypt, during three successive rice growing seasons 2010, 2011 and 2012 aiming to establish combiners that may have drought tolerance characters by hybridization between local sensitive and imported tolerant rice cultivars which will be subjected to aggressive Simple Sequence Repeat (SSR) molecular technique. So, eight genotypes namely; Moroberekan, IET1444, Azucena, IRAT170, GZ530-20-10, Giza177, Giza 178 and Sakha101 were chosen for line by tester cross. The hybrid grains were grown in 2011 as F1 and transplanted in a randomized complete block design (RCBD), with three replications, (each F1 cross transplanted between its parents). All the genotypes (eight parents and $15 \mathrm{~F} 1$ crosses) were planted under both normal and imposed drought conditions.

The obtained results exhibited that, the parents Moroberekan, IET 1444, Giza 178 and Sakha 101 and the F1 crosses involved these parents, in particular the crosses Moroberekan x Giza177 and IET 1444 x Sakha 101 showed the most favorable mean performances values for root, yield and physiological characters, under stress conditions. Moreover, under drought stress, the following F1 crosses; IET $1444 \mathrm{x}$ Giza177, IRAT 17 x Sakha101 show remarkable increase in the mean performance of average panicle length, average number of panicles per plant, average grain yield per plant as well as harvest index. However, insignificant heterotic effects were recorded for average root volume (RV) with the F1 combiner; GZ350-20-10 x Giza178. Neverthless, root to shoot ratio (R:S) did not show insignificant heterosis effects under drought condition.

The most desirable crosses under normal and drought stress were; Moroberekan x Giza177, Moroberekan x Sakha101, IET 1444 x Giza178, IET 1444 x Sakha101. Since these crosses maintained the most favorable shoot, root, yield and physiological characters under both normal and drought stress conditions. The vigorous growth of $\mathrm{F} 1$ rice hybrids may partially attributed to the development and function of the root system. Also, it was found that F1 hybrid surpassed parents in the total root length, number. of root per plant. As a result, the root system of F1 hybrids was not only greater in volume, but also longer in length. Additionally, root to shoot ratio showed higher values than that of parents.

Signficant GCV estimates were recorded for all the studied traits except the parents IET 1444 for average root volume per plant and the parent Giza 178 for root to shoot ratio under normal condition and Giza 177 for average number of roots per plant for number of roots per plant. Also, signficant GCV estimates were recorded for all the studied traits except the parents IRAT 170, Giza 177 and Giza 178 for average relative water content.
\end{abstract}


The studied root, yield and physiological characters showed significant positive estimates of SCA estimates for F1 combiners; Moroberekan x Giza177, Moroberekan x Giza178, IIET 1444 x Giza178 and IET 1444 x Sakha101 under normal and drought conditions. The most common crosses for the studied characters were IET $1444 \mathrm{x}$ Sakha 101, IRAT 170 x Giza178,Moroberekan x Sakha 101 and IET 144 x Giza 177.

Keywords: Oryza sativa L, drought stress, root, yield, physiology, heterosis, general and specific combining ability.

\section{INTRODUCTION}

Drought is a major abiotic stress that causes severe yield loss in rice as a staple food crop. Improvement of drought resistant rice varieties has become an urgent task under the background of global crisis of water resource. Genetic resources played very important roles in crop genetic improvement, especially intargeting the resistance to biotic or abiotic stresses. Wild rice accessions has great contribution in rice breeding by providing resistance genes (e.g. Xa21, BPH14, BPH15) (Ronald et al.,1992; Song et al.,1995; Yang et al., 2004; Du et al., 2009; Hu et al., 2012). It was also reported that wild rice can carry positive alleles of QTLs influencing grain yield or quality (Xiao et al., 1998; Fu et al.,2010; Mallikarjuna Swamy et al.,2011).There are tremendous differences in growth habits between rice genotypes, or among wild rice species (Oka,1974; Vaughan, 1994; Cai and Morishima, 2006; Tan et al., 2008). Replicated individuals with consistent genotypes and approximate growth situation could be developed via 1-2 rounds of tiller trans planting. As the identification of resistant genotypesto drought or other abiotic stresses heavily depends on population size and growth stage of plant (Boonjung and Fukai, 1996) very few reports have been published on screening of drought resistance in rice species. Thanh et al. (2006) obtained 39 drought resistant BC1F2 lines by backcrossing. Zhang et al. (2006) developed a population of 159 introgression lines using an elite indica variety Guichao No2 asthe receptor and Dongxiang wild rice (O. rufipogon) as the donor. The breeding line, IL23, contained two QTLs of drought resistance from the wild rice accession. This study aimed to establish new rice combiners that may have drought tolerance characters by hybridization between local sensitive and imported tolerant rice cultivars which will be subjected to aggressive SSR molecular technique.

\section{MATERIALS AND METHODS}

The present study was carried out at the Experimental Farm of the Rice Research and Training Center (RRTC), Sakha, Kafer EL-Shiekh, Egypt, during three successive rice growing seasons 2010, 2011 and 2012.

\section{I- Plant Material}

Eight genotypes namely; Moroberekan, IET1444, Azucena, IRAT170, GZ530-20-10, Giza177, Giza 178 and Sakha101 were chosen based on the previous studies that describes these genotypes with wide range of variation towards drought sress due to their different genetic background. The 
introduced varieties Moroberekan, IET1444 and Azusena were used as drought resistant while, IRAT170, GZ530-20-10 and Giza178 were used as moderate resistant and Giza177 and Sakha101 were used as drought susceptible.

\section{II- Field work procedures}

The above mentioned eight rice genotypes utilized in this study were grown in three sowing dates during 2010 season, parents growing with 10 days intervals to overcome the difference of heading date among them. Thirty days after sowing, seedlings of each genotype were individually transplanted in the permanent field. A line by tester cross was carried out among the eight parents at flowering to produce F1 hybrid grains. Bulk emasculation method was practiced by using hot water technique according to Jodan (1938) and modified by Butany (1961). The hybrid grains were grown in 2011 rice growing season as F1 plants on the first week of May and plants were transplanted individually after 30 days from sowing in a randomized complete block design (RCBD), with three replications, each replicate consisted of three rows for each $\mathrm{F} 1$ cross and its parents (each $\mathrm{F} 1$ cross planted between its parents). All the genotypes (eight parents and $15 \mathrm{~F} 1$ crosses) were planted under both normal and drought conditions (drought stress was imposed by using flush irrigation every 12 days without standing water after irrigation). All other agricultural practices were used.

\section{The studied traits}

1. Root characters under study were, maximum root length $(\mathrm{cm})$, rnoot volume $(\mathrm{cm} 3)$, Number of roots plant-1 and root: shoot ratio

2. Yield and yield component characters are; number of panicles/plant, sterility percentage (sterile spikelet were indented by pressing the spikelets with the fingers and counting the empty ones and sterility percentage was calculated), 1000- grain weight, grain yield/plant (g), dry matter $(\mathrm{g})$, harvest index estimated by the formula suggested by Yoshida (1981), drought susceptibility index determined according to the formula given by Ali Dib et al, 1990.

3. Physiological and chemical characters are; leaf rolling on methods proposed by De Data et al, (1988), leaf angle, according to Yoshida, (1976), flag Leaf area (cm2) according to following formula: leaf area $=\mathrm{Kx}$ leaf length $x$ leaf width where $K=0.75$, chlorophyll content, nitrogen content $(\mathrm{N})$ according to Barrs and Weatherly (1962), potassium content (K), according to Cottenie et al, (1982), relative water content was determined by the method of Barrs and Weatherly (1962), water use efficiency.

\section{Line $\mathbf{x}$ tester statistical analysis:}

The obtained data were subjected to the convenient statistical analysis by using the analysis of variances for randomized complete blocks design as suggested by Panse and Sukhatme (1954) to test the significance of differences among the genotypes (lines, testers and their F1 hybrids). 


\section{RESULTS AND DISCUSSION}

\section{Mean performance of the studied F1 genotypes \\ 1.1. Mean performance of root characters}

The studied root characters; number of roots per plant (NRP), maximum root length (MRL), root volume (ROV) and root to shoot ratio (RSR) are presented in Table (1). The mean performance of the studied root characters under drought stress as compared with normal condition showed significant decrease with very few exceptions especially with root shoot ratio trait.

It is evident that number of roots per plant (NRP), illustrate that, under normal condition, the parents Morobroken, Asucena and Sakha 101 scored the highest number of roots per plant values of 298.63, 278.98 and 278.94 for the three studied parents, respectively. On the other hand the parents Morobroken, Asucena and IRAT170, under drought stress displayed the highest mean values of $249.10,245.88$ and 303.80 respectively. While, other parents GZ350-20-10 and Giza 177 scored the lowest mean value of 225.05 and 225.05 respectively under normal condition. The corresponded mean values under drought stress were 201.21 and 211.42 respectively. The F1 crosses, under normal condition, Morobroken x Giza 178, Morobroken x Giza 177 and IRAT170 $x$ Giza 178 scored the highest mean values. On the other hand, the crosses GZ350-20-10 x Giza 177, and GZ350-20-10 x Sakha 101 showed the lowest mean values for all irrigation conditions $(236.94,241.36$, 225.40 , and 229.60, respectively.

Data of maximum root length (MRL) illustrate that, under normal conditions, drought stress and their combined, of the parents Moroberekan, Azucena and IET 444 scored, the deepest root length (38.02, 35.40 and $34.09 \mathrm{~cm}),(30.89,28.07$ and $26.11 \mathrm{~cm})$ and $(34.45,31.73$ and $30.10 \mathrm{~cm})$, respectively. While Giza 177, Sakha101, and Giza 178 scored the shortest root length. The measured root lengths were $(21.96,25.00$ and $23.92 \mathrm{~cm})$, $(18.20,20.17$ and $21.09 \mathrm{~cm})$ and $(20.08,22.58$ and $22.50 \mathrm{~cm})$. It is evident that, under normal conditions, drought stress and their combined of the crosses, IRAT 170 x Giza177, Moroberekan x Giza177 and Moroberekan x Giza178 scored the deepest root lengths of $(50.91,48.21$ and $47.01 \mathrm{~cm})$, $(34.09,39.58$ and $38.67 \mathrm{~cm})$ and $(42.50,43.89$ and $42.84 \mathrm{~cm})$. Reversely, the crosses GZ350-20-10 x Sakha 101 and GZ350-20-10 x Giza 177 showed the lowest mean values of $(27.89$ and $31.76 \mathrm{~cm}),(22.94$ and $29.14 \mathrm{~cm})$ and $(25.41$ and $30.45 \mathrm{~cm})$ arranged in the same order.

Root volume (ROV), data in Table (1) state that the parent Moroberekan exhibited the highest root volume values of $67.91,58.70$ and $63.30 \mathrm{~cm} 3$ under normal, drought stress and their combined conditions. While the parent Giza 178 showed the highest mean value $63.72 \mathrm{~cm} 3$ under normal condition but, under drought stress, the highest value $(52.11 \mathrm{~cm} 3)$ was scored with the parent IRAT 170. Conversely, the parent GZ350-20-10 recorded the lowest mean value of $47.31 \mathrm{~cm} 3$ under normal condition. The parent Giza 177 showed the lowest root volume value $33.98 \mathrm{~cm} 3$ under drought condition. The crosses, Moroberekan x Giza177 (75.93, 65.63 and $70.78 \mathrm{~cm} 3)$, Moroberekan x Giza178 (71.3, 62.00 and $66.86 \mathrm{~cm} 3)$, and IET $1444 \times$ 
Sakha101 $(70.21,60.69$ and $65.45 \mathrm{~cm} 3)$ recorded the highest mean values at normal conditions, drought stress and their combined conditions. In contrast the crosses, GZ350-20-10 x Giza 177 (50.37, 43.54 and $46.95 \mathrm{~cm} 3$ ), and GZ350-20-10 x Sakha 101(51.12, 44.19 and $47.65 \mathrm{~cm} 3)$ showed the lowest root volume values under normal condition.

Data of root to shoot ratio (RSR) being presented in Table (1) prove that the parent Giza 178 recorded the highest root to shoot ratio 0.75 under normal condition. As well, Moroberekan showed the highest mean value 0.66 under drought condition. Nevertheless, the parent GZ350-20-10 offers the lowest ratio 0.66 under normal condition. However, Giza 177 scored the lowest root to shoot ratio 0.073 under drought conditions. Another trend was observer among crosses, Moroberekan x Giza177 (0.72, 0.63 and 0.67), IET $1444 \times$ Sakha101 $(0.69,0.63$ and 0.66) and IRAT $170 \times$ Giza178 (0.69, 0.63 and 0.65 ) showed the higher mean ratios under normal, drought stress and their combined. On the other hand, the crosses, GZ350-20-10 x Giza 177(50.37, 43.54 and 46.95), and GZ350-20-10 x Sakha 101(51.12, 44.19 and 47.65) showed the lowest ratios for normal, drought stress and combined conditions, respectively.

Table (1): Mean performances of root characters for the studied eight parents and the fifteen F1 crosses as affected by normal and drought stress and their combined data

\begin{tabular}{|c|c|c|c|c|c|c|c|c|c|c|c|c|}
\hline \multirow{2}{*}{\begin{tabular}{|l} 
Character \\
Genotypes
\end{tabular}} & \multicolumn{3}{|c|}{ Root volume } & \multicolumn{3}{|c|}{ Root :shoot ratio } & \multicolumn{3}{|c|}{$\begin{array}{c}\text { Maximum root } \\
\text { length }\end{array}$} & \multicolumn{3}{|c|}{ Number of roots } \\
\hline & $\mathbf{N}$ & $\mathbf{S}$ & C & $\mathbf{N}$ & $\mathbf{S}$ & C & $\mathbf{N}$ & S & C & $\mathbf{N}$ & $\mathbf{S}$ & C \\
\hline & & & & & & & 38.02 & & & & & \\
\hline & & & & & & & & & & & & \\
\hline & & & & & & & & & & & & \\
\hline & & & & & & & & & & & & \\
\hline & & & & & & & & & & & & \\
\hline & & & & & & & & & & & & \\
\hline & & & & & & & & & & & & \\
\hline & & & & & & & & & & & & \\
\hline & & & & & & & 48. & & 43. & & & \\
\hline & & & & & & & 7.01 & 38 & \begin{tabular}{|l|l|}
42.8 \\
\end{tabular} & & & \\
\hline & 44 & & & & & & 0.29 & 36.70 & 38.4 & & & \\
\hline & & & & & & & 1.24 & 36.71 & & & & \\
\hline & 67.92 & & & & & & 5.82 & 37.69 & & & & \\
\hline & & & & & & & & & & & & \\
\hline & & & & & & & & & & & & \\
\hline & & & & & & & & & & & & \\
\hline & & & & & & & 44.61 & 28.18 & 36.395 & 300 & & \\
\hline & 66.78 & 57.72 & & & & & 50.91 & 34.09 & 42.5 & 299. & & \\
\hline & 69.07 & 59.70 & 64.385 & & & & 45.96 & 36.70 & 41.33 & 305 & & 8.46 \\
\hline & 63.73 & 55.08 & 59.405 & 0.63 & & \begin{tabular}{|l|}
0.56 \\
\end{tabular} & 42.37 & 33.75 & 38.06 & 286.86 & & 279.88 \\
\hline & 50.37 & 43.54 & 46.955 & & & 0.43 & 31.76 & 29.14 & 30.45 & & & \\
\hline & 53.42 & 46. & & & 0.4 & 0.45 & 35.06 & 28.84 & 31.9 & & & \\
\hline & 51.12 & 44.1 & 47.6 & & & 0.41 & 27.89 & 22.94 & 25.415 & 241.36 & & \\
\hline thes & \begin{tabular}{|l|}
2.39 \\
\end{tabular} & & & 0.016 & 0.01 & & 1.34 & 0.79 & & 11.95 & & \\
\hline
\end{tabular}


The observed inhibition in root growth resulted from drought stress is commonly reported by many authors; Levitt (1972), O'Toole and Chang (1979), Blum (1982), O'Toole and De Datta (1986), Passioura (1982), Yoshida and Hasegawa (1982) and O'Toole and De Datta (1986). Generally, the parents Moroberekan, IRAT 170, IET 1444 and Sakha 101 and the F1 crosses involved these parents, in particular the crosses Moroberekan $x$ Giza177 and Moroberekanx Giza178 showed the most favorable mean performances values for shoot characters, under stress conditions. The enhancement of the above mentioned parents for the studied root characters under drought condition was early reported by many investigators among them; Blum (1982), Passioura (1982), Yoshida and Hasegawa (1982), O'Toole and De Datta (1986), Sharma and Koranne (1995), Yogameenashi et al. (2003), Fahmi et al. (2004), Sedeek (2006). Moreover, drought avoidance may be performed by maintenance of turgor through increased root depth, efficient root system and by reduction of water lost (O'Tool and Moya 1978, Begg 1980). According to the results, the reduction of root characters of rice plants under drought stress may be relatively mild, so plants may possess the ability to avoid drought.

\subsection{Mean performance of yield and its component}

The mean performances of yield and its component characters for parents and $\mathrm{F} 1$ crosses grown under normal and drought stress as well as their combined conditions are listed in Table (2). Statistically data showed significant differences among all studied genotypes for all yield and its component studied characters as shown in Table ( ).

Data of average plant grain yield, (PGY) demonstrate that, under normal condition, the parents Sakha 101, Giza 178 and Giza 177 yielded the highest mean value $(41.96,39.74$ and $36.00 \mathrm{~g} /$ plant) respectively, while under drought stress the parents Giza 178 IET 444 and Azucena produced the highest grain yield values $(27.58,23.38$ and $22.67 \mathrm{~g} / \mathrm{plant})$, respectively. On the other hand, under normal condition, Moroberekan and IRAT 170 parents showed the lowest mean values (25.81 and $26.67 \mathrm{~g} / \mathrm{plant}$ ). Nevertheless, under drought stress, the parents Giza 177 and Sakha 101 yielded the lowest grain yield per plant 17.86 and $20.16 \mathrm{~g}$. The studied F1 crosses; IET $1444 \times$ Sakha101, Moroberekan x Giza178 and Azucena x Giza178, under normal condition, produced the highest mean grain yied 43.71, 42.36 and 42.09 g/plant, respectively. Conversely, the crosses GZ350-20-10 x Giza177, GZ350-20-10 x Sakha101 and GZ350-20-10 x Giza178 yielded the lowest mean grain yield per plant under normal, drought stress and combined, respectively. The corresponded mean grain yield per plant values were; (34.04, 23.20 and $28.62 \mathrm{~g} /$ plant), (35.05, 20.65 and $27.85 \mathrm{~g} /$ plant) and (36.66, 22.03 and $29.35 \mathrm{~g} / \mathrm{plant}$ ), for the mentioned crosses arranged in the same order.

Concerning average panicle length (PAL) data prove that the studied parents Moroberekan, IRAT 170 and Azucena showed the longest panicles as their panicle lengths were, $(28.63,27.39$ and $25.98 \mathrm{~cm}),(25.81,23.30$ and $24.39 \mathrm{~cm})$ and $(27.2,24.64$ and25.89 $\mathrm{cm})$, for normal, drought stress and their combined, respectively. 
J. Plant Production, Mansoura Univ., Vol. 4 (1), January, 2013

2 
Whilst, the parents IET 444 and Sakha101 showed the lowest mean value $(25.81$ and $26.67 \mathrm{~cm})$ under normal condition. The other parents Giza 177 and Sakha 101 showed the shortest mean panicle length values (23.18 and $24.34 \mathrm{~cm}$ ) under normal condition. On the contrary, under drought stress the parents Sakha 101 and Giza 177 showed the lowest mean panicle length values 20.67 and $21.15 \mathrm{~cm}$, respectively.

The studied F1 crosses; Moroberekan x Sakha101, IET $1444 \times$ Sakha 101, Moroberekan x Giza 178 and IRAT 170 x Giza177, under normal, drought stress and their combined respectively, produced the longest mean panicle length. The recorded panicle lengths were $(28.91,27.51$ and $28.21 \mathrm{~cm}),(28.02,26.01$ and 27.02), (27.53, 25.88 and 26.71), (27.50, 25.10 and $26.30 \mathrm{~cm})$ and $(27.18,25.42$ and $26.30 \mathrm{~cm})$, for the above mentioned crosses arranged in the same order. On the other hand, the crosses GZ35020-10 x Giza178, GZ350-20-10 x Giza 177 and IRAT 170 x Sakha 101 produced the shortest mean panicle length under normal, drought stress and combined, respectively. The corresponded mean panicle length values were; (22.66, 22.91 and $22.79 \mathrm{~cm}),(24.26,22.78$ and $23.52 \mathrm{~cm})$ and $(24.16,22.60$ and $23.38 \mathrm{~cm}$ ), for the mentioned crosses arranged in the same order.

As for number of panicles per plant (NPP), data indicate that the parents Giza 178, Sakha 101 and Giza 177 produced the highest number of panicles per plant values under normal, drought stress and their combined respectively. The corresponded recorded number of panicles values were; (23.46, 17.12 and 20.29 panicle/plant), (18.14, 13.95 and 16.05 panicle/plant), (22.91, 16.33 and 19.62 panicle/plant) arranged in the same order. On the other hand GZ350-20-10 and IET444 showed the lowest mean value (13.13, 9.88 and 11.51 per plant) and (13.78, 10.75 and 12.27 per plant) under normal, drought stress and their combined respectively. It is realized also that the crosses, Moroberekan x Giza 178 produced (23.03, 14.75 and 18.89) followed by Moroberekan $\times$ Sakha 101 which averaged (21.09, 12.36 and 16.73) and Moroberekan x Giza 177 that gave (20.10, 13.98 and 17.04) under normal, drought stress and their combined respectively. The lowest scored mean number of panicles per plant were achieved by the crosses, GZ350-20-10 x Sakha101 (12.82, 8.74 and 10.78) and GZ350-20-10 x Giza177 (13.66, 9.75 and 11.71), under normal, drought stress and their combined respectively.

Harvest index per plant (HIP) of the studied genotypes showed that the parents; Sakha 101, Giza 178 and Giza 177 attained high harvest index mean values (0.42, 0.33 and 0.38$),(0.39,0.32$ and 0.36$)$ and $(0.39,0.29$ and 0.34) under normal, drought stress and their combined conditions respectively. On the other hand the parents Moroberekan and IRAT 170 showed low mean harvest index values $(0.26,0.26$ and 0.26$)$ and $(0.27,0.25$ and 0.26), under normal, drought stress and their combined conditions respectively. The F1 crosses, Moroberekan x Sakha101 (0.37, 0.32 and 0.34), IET $1444 \times$ Sakha101 (0.37, 0.30 and 0.34) and Azucena x Sakha101 (0.37, 0.29 and 0.33 ) attained high mean harvest index values under normal, drought stress and their combined conditions, respectively. It is also recognized that, the low harvest index mean values were recorded with the 
following F1 crosses; GZ350-20-10 x Sakha101 (0.32, 0.23 and 0.27), GZ350-20-10 x Giza177 (0.32, 0.28 and 0.30) and GZ350-20-10 x Giza178 (0.32, 0.28 and 0.30$)$ under normal, drought stress and their combined conditions, respectively.

Sterility percent $(\mathrm{S}) \%$ was used as a criteria for measuring the direct effect of drought on the average seed set per plant for the studied genotypes, Table (2). The recorded data show that, under normal condition, the parents Giza 178, Sakha 101 and Giza 177 scored the lowest mean value (4.67, 5.39 and $5.63 \%$ ), respectively. The lowest mean value, under drought stress (8.47and 8.59\%) among parents were scored with IRAT170 and Giza 178, respectively. Reversely, under the same condition, Azucena and GZ350-2010 showed relatively highest mean values (8.37and $8.65 \%$ ), respectively. However, Giza 177 and Moroberekan scored the highest sterility mean values $(12.56 \%$ and 12.93$)$ under drought condition. Regarding the the crosses performance it is apparent that the crosses; IIET $1444 \times$ Giza178, Moroberekan x Giza177, Moroberekan x Giza178, Azucena x Giza178, and IET $1444 \times$ Giza177 scored relatively low mean sterility values. The corresponded scored values were; (5.51, 6.74 and 6.13\%), (6.41, 9.28 and $7.85 \%),(7.23,8.98$ and $8.11 \%),(7.24,8.99$ and $8.12 \%)$ and $(7.92,9.51$ and $8.72 \%$ ) under normal, drought stress and their combined conditions respectively. On the other hand, the cross GZ350-20-10x Giza177 showed the highest values of $(11.83,13.44$ and $12.64 \%)$ under normal, drought and the combined conditions, respectively.

The mean performance of the studied genotypes in $\mathrm{F} 1$ with regard to thousand grains weight (TGW), show that the parents Moroberekan and Azucena produced the relatively high mean values for such trait $(3.78,3.56$ and3.67 g) and $(3.63,3.46$ and $3.55 \mathrm{~g})$ under normal, drought and the combined conditions, respectively. However, the Parents Giza 178 and IET 444 showed the lowest TGW mean values, $(2.34,2.13$ and2.24 g) and (2.42, 2.20 and $2.31 \mathrm{~g}$ ) under normal, stress and combined conditions, respectively. AS for the crosses, data proved that the crosses Moroberekan x Giza177, Moroberekan x Giza178, Moroberekan x Sakha101 and Azucena x Giza177 showed comparable high mean value $(3.61,3.53$ and3.57 g) , $(3.57,3.51$ and3.54 g), (3.57, 3.27 and $3.42 \mathrm{~g})$ and $(3.52,3.48$ and $3.50 \mathrm{~g})$ as compared with the rest of the studied crosses. However, the cross Giza IIET $1444 \times$ Giza178 produced the lowest mean value $(2.68,2.21$ and $2.45 \mathrm{~g})$ under normal, drought stress and combined conditions, respectively.

Generally, the parents Moroberekan, Azucena, IRAT 170, IET 1444 and Sakha 101 and the F1 crosses involved these parents, in particular the crosses Moroberekan x Giza177 and Moroberekanx Giza178 showed the most favorable mean performances values for yield and yield components characters, under stress conditions. Moreover, under drought stress, the following F1 crosses; GZ350-20-10 x Giza177, GZ350-20-10 x Giza178, GZ350-20-10 x Sakha101 showed remarkable increase in the mean performance of average panicle length per plant, average grain yield per plant as well as harvest index. These results are in accordance with those reported by Young and Virmani (1990), Reddy et al. (1991), Ramalingam et 
al. (1994), El-Mowafi (2001), El-Mowafi and Abou Shousha (2003), Hammoud (2004), El-Mowafi and Abd El-Hadi (2005).

\subsection{Mean performance of the physiological characters}

The mean performances of the studied physiological characters are listed in Table (3). Statistically data proved significant differences among all studied genotypes for all the studied characters as shown in Table (3).

Regarding Leaf rolling score (LRS), it is clear that, all studied genotypes, grown under drought conditions showed variable symptoms of rolled leaf. Since, minimal leaf rolling score was associated with the following parents; IET 1444, Moroberekan, BG 35-1 and Giza 178. It is also evident that the F1 crosses; IET 1444 X Moroberekan, IET 1444 x BG 35-1 and BG 35-1 x Giza 178 showed relatively low rolling score (1-3). This result indicate the drought tolerance of these genotypes as compared with the other studied genotypes. At heading stage the sensitive parents; (Sakha 101) and Giza 177 and the crosses GZ350-20-10x Sakha101, GZ350-20-10x Giza178, GZ350-20-10x Giza177, and IRAT $170 \times$ Sakha101 showed sever drought symptoms that scored high rolled leaf level score 7-9. The studied fifteen crossed genotypes showed six genotypes namely; (GZ350-20-10 x Sakha101, GZ350-20-10 x Giza178, GZ350-20-10 x Giza177, and IRAT 170 x Sakha101) which appeared the worst; three genotypes (Azucena $\times$ Sakha101, IIET $1444 \times$ Giza178 and IRAT $170 \times$ Giza177) showed average score (5) and two genotypes (Azucena x Giza177 and Azucena x Giza178) had mild symptom (grade 2-3). It is worthy to mention that, from the comparison between the hybrid genotypes, the variation in drought resistance among the sensitive parents is parallel to that among their hybrid genotypes. Drought sensitive parent Sakha 101 is the most sensitive genotype to water deficit as it had severe leaf desiccation and growth inhabitation in comparison with the plants under normal condition. As the hybrids of this parent, (Moroberekan $\mathrm{x}$ Sakha101, IET 1444 x Sakha101 and GZ350-20-10x Sakha101) had relatively high to mild levels of leaf rolling but less desiccation, similar to most of hybrid combination.

Data presented in Table (4) concerned the flag leaf area (FLA). It realized that the parents Moroberekan, Azucena maintained the highest mean flag leaf area. Where, the recorded values of the parents were (41.83 and, $35.31 \mathrm{~cm} 2)$, (39.55 and $37.31 \mathrm{~cm} 2)$ for normal and drought sress, respectively. However, the crosses (IRAT $170 \times$ Giza177), (Azucena $x$ Giza177) and (Moroberekan $x$ Giza177) averagee the following mean values (41.35 and $38.68 \mathrm{~cm} 2),(41.91$ and $39.21 \mathrm{~cm} 2)$ and $(40.85$ and $38.21 \mathrm{~cm} 2)$ under normal and drought stress conditions, respectively. Reversely, the lowest flag leaf area mean values were recorded with Sakha 101, Giza 178, (GZ350-20-10 x Giza178) and (GZ350-20-10 x Sakha101). These genotypes had (26.90 and $25.30 \mathrm{~cm} 2),(28.06$ and $26.24 \mathrm{~cm} 2),(32.92$ and $30.79 \mathrm{~cm} 2)$ and (33.92 and $31.46 \mathrm{~cm} 2)$ under normal and drought stress conditions, respectively.

Leaf chlorophyll contents $(\mathrm{mg} / \mathrm{g}),(\mathrm{CH})$ of all studied genotypes showed considerable variation. The lowest chlorophyll content value was associated with the parents Sakha 101 (44.90 and 34.99 mg/g) followed by Giza 177 
(42.92 and $38.62 \mathrm{mg} / \mathrm{g}$ ) while, the parent GZ350-20-10 scored the lowest mean value $(35.80,33.13$ and $34.47 \mathrm{mg} / \mathrm{g})$ under normal and stress conditions, respectively. Considerable high chlorophyll content mean values were scored in the following f1 crosses; IRAT $170 \times$ Giza178 (42.06 and $38.93 \mathrm{mg} / \mathrm{g}$ ), Moroberekan x Giza177 (41.85 and $38.73 \mathrm{mg} / \mathrm{g}$ ), Moroberekan $x$ Giza178 (41.76 and $38.65 \mathrm{mg} / \mathrm{g}$ ), and IRAT 170 x Sakha101 (41.74 and $38.63 \mathrm{mg} / \mathrm{g}$ ) under normal and drought stress. On the other hand the $\mathrm{F} 1$ crosses; GZ350-20-10 x Sakha101, GZ350-20-10 x Giza178 , and GZ35020-10 x Giza177 genotypes had the lowest mean values (35.80 and 33.13 $\mathrm{mg} / \mathrm{g}$ ), (31.92 and $29.54 \mathrm{mg} / \mathrm{g}),(32.63$ and $30.21 \mathrm{mg} / \mathrm{g})$, and (34.71 and $32.13 \mathrm{mg} / \mathrm{g}$ ) under normal and drought stress conditions, respectively.

Relatively high nitrogen content $(\mathrm{mg} / \mathrm{g})(\mathrm{N})$, mean values were established in the following parents genotypes; Giza 178 (0.49 and 0.43 $\mathrm{mg} / \mathrm{g})$, Giza $177(0.45$ and $0.36 \mathrm{mg} / \mathrm{g})$, Moroberekan $(0.43$ and $0.39 \mathrm{mg} / \mathrm{g})$. In addition the F1 crosses; Moroberekan x Giza178 $(0.51$ and $0.53 \mathrm{mg} / \mathrm{g})$ and IIET $1444 \times$ Giza178 (0.50 and $0.49 \mathrm{mg} / \mathrm{g})$ produced considerably high mean values for such trait, under both normal and drought conditions, respectively. While the parents genotypes IET $444(0.30$ and $0.29 \mathrm{mg} / \mathrm{g})$, GZ350-20-10 (0.31 and $0.28 \mathrm{mg} / \mathrm{g}$ ) and the crosses GZ350-20-10 x Giza177 (0.27 and 0.23 $\mathrm{mg} / \mathrm{g}$ ) and GZ350-20-10 x Sakha101 (0.32 and $0.29 \mathrm{mg} / \mathrm{g})$ produced relatively low mean values under normal and drought stress conditions, respectively.

Relatively high potassium content $(\mathrm{K})(\mathrm{mg} / \mathrm{g})$, mean values were scored in the studied parents; (Moroberekan) $(0.76$ and $0.68 \mathrm{mg} / \mathrm{g}$ ), Azucena $(0.71$ and $0.65 \mathrm{mg} / \mathrm{g}$ ). Moreover, the crosses; IET $1444 \times$ Sakha101 (0.91 and 0.81 $\mathrm{mg} / \mathrm{g})$, IIET $1444 \times$ Giza178 $(0.89$ and $0.80 \mathrm{mg} / \mathrm{g})$ and Moroberekan $\times$ Giza178 $(0.86$ and $0.79 \mathrm{mg} / \mathrm{g})$ produced relatively high potassium content under both normal and drought conditions, respectively. While the parents genotypes Giza 177 (0.56 and 0.50 mg/g), GZ350-20-10 (0.64 and 0.56 $\mathrm{mg} / \mathrm{g}$ ) and the crosses GZ350-20-10 x Giza177 (0.47 and $0.40 \mathrm{mg} / \mathrm{g}$ ), GZ350-20-10 x Sakha101 (0.56 and 0.49 mg/g) and GZ350-20-10 x Giza177 $(0.61$ and $0.55 \mathrm{mg} / \mathrm{g}$ ) gave relatively low mean potassium content values under normal and drought stress conditions, respectively.

Concerning relative water content (RWC), data reveal that, the highest mean values of the genotypes, IRAT 170 (81.32 and 94.64), Giza 178 (80.20 and 93.67), IET 1444, (79.40 and) Moroberekan x Giza 177 (81.06 and 94.67), Moroberekan $x$ Sakha101 (81.04 and 94.64) and IET 1444 x Sakha101 (80.49 and 94.01) under normal and stress conditions, respectively. On the other hand, the lowest values of relative water content scored with the genotypes Sakha 101 (63.00 and 73.58), GZ350-20-10 (69.03 and 80.62), GZ350-20-10x Giza177 (60.95 and 71.18) and Azucena x Sakha101 (63.28 and 73.91) for the two studied normal and drought stress conditions.

Moreover, the excessive mean water use efficiency, (WUE) values were obtained with the parents; Sakha 101 (0.73 and 0.60), Giza 178 (0.70 and 0.83 ) and IET 444 (0.50 and 0.70). However, the crosses; IET $1444 \times$ Sakha101 (0.76 and 0.9), Moroberekan x Giza 178 (0.74 and 1.00), Azucena 
$x$ Giza178 (0.74 and 0.91) and IIET 1444 x Giza178 (0.72 and 0.93) showed the same relatively high water use efficiency mean values under normal and drought stress conditions, respectively. While the parent Moroberekan $(0.45$ and 0.66) and the crosses GZ350-20-10 x Giza177 (0.60 and 0.70), GZ35020-10 x Sakha101 (0.61 and 0.62) showed lowest mean values under normal and drought stress conditions, respectively.

Table (3): Mean performances of physiological characters for the studied eight parents and fifteen $\mathrm{F} 1$ crosses as affected by normal and drought stress conditions

\begin{tabular}{|c|c|c|c|c|c|c|c|c|c|c|c|c|c|c|}
\hline \multirow{2}{*}{\begin{tabular}{|l|} 
Characters \\
Genotypes
\end{tabular}} & \multicolumn{2}{|c|}{$\begin{array}{l}\text { Leaf } \\
\text { rolling }\end{array}$} & \multicolumn{2}{|c|}{$\begin{array}{c}\text { Flag leaf } \\
\text { area }\end{array}$} & \multicolumn{2}{|c|}{$\begin{array}{c}\text { Chlorophyll } \\
\text { content }\end{array}$} & \multicolumn{2}{|c|}{$\begin{array}{c}\text { Nitrogen } \\
\text { content }\end{array}$} & \multicolumn{2}{|c|}{$\begin{array}{c}\text { Potassium } \\
\text { content }\end{array}$} & \multicolumn{2}{|c|}{$\begin{array}{c}\text { Relative } \\
\text { water } \\
\text { content }\end{array}$} & \multicolumn{2}{|c|}{$\begin{array}{l}\text { Water use } \\
\text { efficiency }\end{array}$} \\
\hline & $\mathbf{N}$ & $\mathbf{S}$ & $\mathbf{N}$ & $\mathbf{S}$ & $\mathbf{N}$ & $S$ & $\mathbf{N}$ & $\mathbf{S}$ & $\mathbf{N}$ & $S$ & $\mathbf{N}$ & S & $\mathbf{N}$ & $\mathbf{S}$ \\
\hline \begin{tabular}{|l|} 
P1 \\
\end{tabular} & 2 & 3 & 41.83 & 35.31 & 37.96 & 34.73 & 0.43 & 0.39 & 0.76 & 0.68 & 76.33 & 89.14 & 0.45 & 0.66 \\
\hline P2 & 2 & 3 & 39.55 & 37.31 & 41.88 & 38.77 & 0.40 & 0.34 & 0.71 & 0.65 & 77.07 & 90.01 & 0.47 & 0.68 \\
\hline P3 & 1 & 3 & & 33.64 & 37.30 & 34.53 & & 0.29 & 69 & 62 & 79.40 & 92.73 & 30.50 & 0.70 \\
\hline P4 & 1 & 5 & & & & 36.82 & & 30 & & & & 94.98 & & 0.64 \\
\hline P5 & 2 & 5 & & & & 13 & & 0.28 & 64 & 56 & 69.03 & 80.62 & 58 & 68 \\
\hline P6 & 1 & 7 & & & & 3.62 & 0.45 & .36 & 56 & & & 83.01 & & 0.54 \\
\hline P7 & 1 & 5 & & & & & 0.4 & 0.43 & 70 & & 80.2 & 93.67 & & 0.83 \\
\hline P8 & 1 & 9 & 26.9 & & & 34.99 & 0.42 & 0.30 & 0.66 & 0.58 & 63.00 & 73.58 & & 0.60 \\
\hline P1XP6 & 3 & 3 & & & & 38.73 & 0.45 & 0.39 & \begin{tabular}{|l|}
0.71 \\
\end{tabular} & \begin{tabular}{|l|}
0.68 \\
\end{tabular} & 81.06 & 94.67 & $\begin{array}{ll}70.67 \\
\end{array}$ & 0.80 \\
\hline $\mathbf{P}$ & 3 & 3 & & & & & & 0.53 & & 79 & 17 & 83.13 & 74 & 1.00 \\
\hline & 7 & & & & & & 0. & 0.37 & 71 & 0.67 & 04 & 94.64 & & 0.88 \\
\hline $\mathbf{P}$ & 3 & 3 & 41. & & & 38.27 & 0.44 & 0.38 & 0.68 & 0.59 & 71.64 & 83.67 & & 0.77 \\
\hline $\mathbf{P}$ & 2 & & & & & .42 & 0.4 & 0.39 & 0.71 & 0.68 & \begin{tabular}{|l|}
77.25 \\
\end{tabular} & 90.22 & & 0.91 \\
\hline P2XP8 & 5 & 5 & 37.79 & 35.35 & 39.46 & 36.52 & 0.38 & 0.38 & 0.60 & 0.53 & 63.28 & 73.91 & 0.70 & 0.75 \\
\hline P3XP6 & 7 & 7 & 35.72 & 33.41 & 35.72 & 33.06 & 0.49 & 0.42 & 0.77 & 0.69 & 78.10 & 91.21 & 0.63 & 0.78 \\
\hline P3XP7 & 5 & 5 & 36.07 & 33.74 & 38.00 & 35.17 & 0.50 & 0.49 & 0.89 & 0.80 & 79.85 & 93.26 & 0.72 & 0.93 \\
\hline & 7 & 7 & 34. & 32. & & & 0.4 & 0.46 & 0.91 & 0.81 & 80.49 & 94.01 & & 0.96 \\
\hline & 5 & 5 & 41. & & & & 0.4 & 0.35 & 0.72 & 0.67 & 74.88 & 87.45 & & 0.93 \\
\hline $\mathbf{P}$ & 3 & 3 & & & & & 0.42 & 0.36 & 0.77 & 0.70 & 71.64 & 83.67 & & 0.76 \\
\hline $\mathbf{P}$ & 7 & 7 & 38.8 & 36.33 & & 38.63 & 0.41 & 0.35 & 0.70 & 0.62 & 75.07 & 87.68 & & 0.81 \\
\hline P5XP6 & 7 & 7 & 35.71 & 33.41 & 34.71 & 32.13 & 0.27 & 0.23 & 0.47 & 0.40 & 60.95 & \begin{tabular}{|l|}
71.18 \\
\end{tabular} & 30.60 & 0.70 \\
\hline P5XP7 & 7 & 7 & 33.63 & 31.46 & 32.63 & 30.21 & 0.33 & 0.30 & 0.61 & 0.55 & 68.04 & 79.47 & 70.64 & 0.66 \\
\hline P5XP8 & 9 & 9 & 32.92 & 30.79 & 31.92 & 29.54 & 0.32 & 0.29 & 0.56 & 0.49 & 69.31 & 80.95 & 50.61 & 0.62 \\
\hline LSD 5\% & 1.97 & 1.44 & 0.6 & 0.54 & 1.36 & 1.11 & 0.006 & 0.006 & 0.01 & 0.01 & 1.46 & 1.56 & 1.16 & 1.05 \\
\hline
\end{tabular}

The obtained results proved that, generally, the parents Moroberekan, GZ350-20-10, Giza 178 and Sakha 101 as well as the F1 crosses involved these parents, in particular the crosses Moroberekan x Giza177 and Moroberekanx Giza178 showed the most favorable mean performances values for the studied physiological characters, under stress conditions. Moreover, under drought stress, the following F1 crosses; GZ350-20-10 x Giza177, IRAT 17 x Sakha101 showed remarkable increase in the mean performance of average flag leaf are, average grain yield per plant as well as harvest index. These results are in accordance with those reported by Young and Virmani (1990), Reddy et al. (1991), Ramalingam et al. (1994), El-Mowafi (2001), El-Mowafi and Abou Shousha (2003), Hammoud (2004), El-Mowafi and Abd El-Hadi (2005). 


\section{Heterosis percentages over mid parents for $F 1$ crosses \\ 2.1. Heterosis percentages of root characters}

Data in Table (4) show that, under drought stress, significant positive heterosis effect was realized for average root volume (RV), in the crosses, Moroberekan x Giza177, Moroberekan x Giza178, Moroberekan x Sakha101, Azucena x Giza177, Azucena x Giza178, Azucena x Sakha101, IET 1444 x Giza177, IIET 1444 x Giza178, IET 1444 x Sakha101, IRAT 170 x Giza177 and IRAT $170 \times$ Giza178. The other studied character, root to shoot ratio (R:S) showed significant estimates with All crosses except Moroberekan x Giza177 and IRAT $170 \times$ Giza177. As well, for maximum root length (MRL) positive significant heterosis effects, under drought condition, were scored with the croses; Moroberekan x Giza177 ,Moroberekanx Giza178, Moroberekan x Sakha101, Azucena x Giza177, Azucena x Giza178, Azucena x Sakha101, IET 1444 x Giza177, IET 1444 x Sakha101, IRAT 170 x Giza177, IRAT 170 x Giza178, IRAT 170 x Sakha101, GZ350-20-10 x Giza177, GZ350-20-10 x Giza178 and GZ35020-10 x Sakha101. Typically similar significant estimates were found for average root number per plant (RNP) in the crosses; Moroberekan x Giza177, Moroberekan x Giza178, Moroberekan x Sakha101, Azucena x Giza177, Azucena x Giza178, Azucena x Sakha101, IET 1444 x Giza177, IIET 1444 x Giza178, IET 1444 x Sakha101, IRAT 170 x Giza177, IRAT 170 x Giza178 and GZ350-20-10 x Giza178.

It is evident that, under drought condition, insignificant heterotic effects were recorded for average root volume (RV) with the F1 combiner; GZ350-20-10 x Giza178. Neverthless, root to shoot ratio (R:S) did not show insignificant heterosis effects under drought condition. In addition, for maximum root length (MRL) insignificant heterosis effects were scored with the F1cross; IIET $1444 \times$ Giza178. Relatively similar insignificant estimates were found for average root number per plant (RNP) in the crosses; IRAT $170 \times$ Sakha101.

\subsection{Heterosis percentages for yield and yield components characters}

Data in Table (5) show the heterosis percentages over mid parents (MP) of yield and its component characters. It is evident that, under drought stress, significant Positive heterosis effects for yield and its component characters were scored for average panicle length (PL) with the crosses; Moroberekan $\times$ Giza177, Moroberekan x Sakha101, Azucena x Giza177, Azucena x Sakha101, IET 1444 x Giza177, IET 1444 x Sakha101 and IRAT $170 \times$ Giza177. The other studied yield character, average number of panicles per plant (NPP) exhibited significant estimates with, Moroberekan x Giza177 , Azucena x Giza177, IET 1444 x Giza177, IIET 1444 x Giza178 and IET 1444 x Sakha101. As well, for average thousand grains weight (1000 G W) significant heterosis effects were scored with the croses; Moroberekan x Giza177, Moroberekanx Giza178, Moroberekan $x$ Sakha101, Azucena x Giza177, Azucena x Giza178, Azucena x Sakha101, IRAT 170 x Giza177, IRAT 170 x Giza178, IRAT 170 x Sakha101 and GZ350-20-10 x Giza178. Typically similar significant estimates were found for average sterility parcentage (S\%) in the crosses; Moroberekan x Giza178, Azucena x Giza177, Azucena x Giza178, IIET 1444 x Giza178, IET 1444 x Sakha101, IRAT 170 x Giza177, IRAT 170 x Giza178, IRAT 170 x Sakha101, GZ350-20-10 x Giza178 and GZ350-20-10 x Sakha101. 
El Banna, M. N. et al.

4 
Comparatively similar insignificant estimates were found for drought susceptibility index (DSI) in the crosses GZ350-20-10x Giza178. Finally insignificant heterotic effects were detected for the average grain yield per plant (GY) with the crosses; Moroberekan $x$ Giza177, Moroberekan $x$ Giza178, Moroberekan x Sakha101, Azucena x Giza177, Azucena x Giza178, Azucena x Sakha101, IET 1444 x Giza177, IIET 1444 x Giza178, IET $1444 \times$ Sakha101, IRAT $170 \times$ Giza177 and IRAT $170 \times$ Giza178. It is worthy to mention that, under drought stress, all the studied F1 crosses showed negative heterosis percentages for harvest index $(\mathrm{HI})$.

Table (5): General combining ability estimates of root characters (5 lines and 3 tester) parents genotypes grown under normal and drought stress and their combined data

\begin{tabular}{|c|c|c|c|c|c|c|c|c|c|c|c|c|}
\hline \multirow{2}{*}{\begin{tabular}{|l|} 
Character \\
Genotype \\
\end{tabular}} & \multicolumn{3}{|c|}{ Root volume } & \multicolumn{3}{|c|}{ Root : shoot ratio } & \multicolumn{3}{|c|}{$\begin{array}{l}\text { Maximum root } \\
\text { length }\end{array}$} & \multicolumn{3}{|c|}{ Number of roots } \\
\hline & $\mathbf{N}$ & S & C & $\mathbf{N}$ & S & C & $\mathbf{N}$ & S & C & $\mathbf{N}$ & S & C \\
\hline & $7.61^{*}$ & & & & & & $4.06^{*}$ & & & & & \\
\hline & & & & & & & & & & & & \\
\hline & & & & & & & & & & & & \\
\hline & 1.7 & & & & & & $5.39^{*}$ & & $3.87^{*}$ & $6.75^{\star}$ & & \\
\hline & $-13.29^{*}$ & & & & & & $-9.54^{*}$ & $-6.35^{*}$ & $-7.94^{*}$ & $-45.6^{*}$ & $-43.4^{*}$ & $-44.5^{\star}$ \\
\hline L.S.D $5 \%$ & 0.56 & & & & & & 0.32 & 0.19 & \begin{tabular}{|l|}
0.19 \\
\end{tabular} & $2.82^{*}$ & 2.90 & 2.07 \\
\hline & -0 . & & & & & & $0.38^{*}$ & & $0.53^{*}$ & & $-1.88^{*}$ & \\
\hline & & & & & & & $1.49^{*}$ & 0.7 & $1.11^{*}$ & & 7. & \\
\hline & & & & & & & $-1.87^{\star}$ & -1.4 & $\mid-1.64^{*}$ & & & \\
\hline S.D 5\% & 0.44 & & & & & & 0.25 & 0.14 & \begin{tabular}{|l|}
0.15 \\
\end{tabular} & $2.19^{\star}$ & 2.25 & 1.60 \\
\hline
\end{tabular}

The significance of heterotic effect showed considerable fluctuation since, insignificant heterosis percentages were recorded for yield and its component characters in some tested F1 combiners under drought condition. Insignificant heterotic effects were recorded for average panicle length $(\mathrm{PL})$ with the crosses; Moroberekan x Giza178, Azucena x Giza178, IIET 1444 x Giza178, IRAT 170 x Giza178, GZ350-20-10 x Giza177 and GZ350-20-10 x Sakha101. While, number of panicles per plant (NPP) showed insignificant estimates with, Moroberekan x Giza178, IRAT 170 x Giza178 and IRAT 170 x Sakha101. As well, for average thousand grains weight (1000GW) insignificant heterosis effects were scored with the croses; IET $1444 \times$ Giza177, IIET 1444 x Giza178, IET 1444 x Sakha101 and GZ350-20-10 x Sakha101. Relatively similar insignificant estimates were found for sterility parcentage (S\%) in the crosses; Moroberekanx Giza178, Azucena $x$ Giza177, Azucena x Giza178, Azucena x Sakha101, and GZ350-20-10 x Sakha101. Comparatively similar insignificant estimates were found for drought susceptibility index (DSI) in the crosses Azucena x Giza178, IIET 1444 x Giza178 and IRAT 170 x Giza178. Similar insignificant estimates were obtained for harvest index $(\mathrm{HI})$ in the following $\mathrm{F} 1$ crosses; Moroberekan $\mathrm{x}$ Sakha101, Azucena x Giza177, IET 1444 x Giza177, IRAT 170 x Giza177 and GZ350-20-10x Giza177. Finally insignificant heterotic effects were detected for the average grain yield per plant (GY) with the crosses, IRAT 170 x Giza178 and GZ350-20-10x Sakha101. 


\subsection{Heterosis percentages over Mid parents for physiological characters}

It is obvious that, under drought stress Table (6), significant positive heterosis effect was realized for average flag leaf area, cm2 (FL), in the crosses, Moroberekan x Giza177, Moroberekan x Giza178, Moroberekan x Sakha101, Azucena x Giza177, Azucena x Giza178, Azucena x Sakha101, IET 1444 x Giza177, IIET 1444 x Giza178, IET 1444 x Sakha101, IRAT 170 x Giza177, IRAT 170 x Giza178, IRAT 170 x Sakha101, GZ350-20-10 x Giza177, GZ350-20-10 x Giza178 and GZ350-20-10 x Sakha101. The other studied character, average chlorophyll content, $\mathrm{mg} / \mathrm{g}(\mathrm{CHC})$ showed significant estimates with All crosses except Moroberekan x Sakha101, Azucena x Giza177, Azucena x Sakha101, IET 1444 x Sakha101, IRAT 170 $x$ Giza177 and IRAT 170 x Giza178. As well, for average nitrogen content $\mathrm{mg} / \mathrm{g}(\mathrm{N})$ significant heterosis effects were scored with the croses; Moroberekan x Giza177, Moroberekan x Giza178, Moroberekan x Sakha101, Azucena x Giza177, Azucena x Sakha101, IET 1444 x Giza177, IIET 1444 x Giza178, IET 1444 x Sakha101, IRAT 170 x Giza177 and IRAT 170 x Sakha101. Typically similar significant estimates were found for potassium content mg/g (K) in the crosses; Moroberekan x Giza177, Moroberekan x Giza178, Moroberekan x Sakha101, Azucena x Giza177, Azucena x Giza178, IET 1444 x Giza177, IIET 1444 x Giza178, IET 1444 x Sakha101, IRAT 170 x Giza177 and IRAT 170 x Giza178. Comparatively similar insignificant estimates were found for relative water content (RWC) in the crosses; Moroberekan x Giza177, Moroberekan x Sakha101, IET 1444 x Giza177, IET 1444 x Sakha101, IRAT 170 x Sakha101 and GZ350-20-10 x Sakha101.

No significant heterosis percentages, under drought condition, were recorded for average flag leaf area $(\mathrm{FL})$, with the tester combiners; Moroberekan x Giza178, Azucena x Giza178, IIET 1444 x Giza178, IRAT 170 x Giza178, GZ350-20-10 x Giza177 and GZ350-20-10 x Sakha101. Neverthless, average chlorophyll content $(\mathrm{CHC})$, showed insignificant estimates with, MoroberekanxSakha101, Azucena x Giza177, Azucena x Sakha101, IET 1444 x Sakha101, IRAT 170 x Giza177 and IRAT 170 x Giza178,. As well, for average nitrogen content $\mathrm{mg} / \mathrm{g}(\mathrm{N})$ insignificant heterosis effects were scored with the croses; Azucena x Giza178, IRAT 170 x Giza178 and GZ350-20-10 x Sakha101. Relatively similar insignificant estimates were found for average potassium content $\mathrm{mg} / \mathrm{g}(\mathrm{K})$ in the crosses; Moroberekan x Sakha101 and Azucena x Giza178. Comparatively similar insignificant estimates were found relative water content (RWC) in the crosses Azucena x Giza178, IIET 1444 x Giza178 and IRAT 170 x Giza177.

The obtained results insured that, the most desirable crosses under normal and drought stress were; Moroberekan x Giza177, Moroberekan x Sakha101, IET 1444 x Giza178, IET 1444 x Sakha101. Since these crosses maintained the most favorable shoot, root, yield and physiological characters under both normal and drought stress conditions. it is noticed that the parent Giza 177 showed negative heterosis percentages for number of days to heading in all crosses. 
J. Plant Production, Mansoura Univ., Vol. 4 (1), January, 2013

6 
These results emphasized that vigorous growth of F1 rice hybrids may partially attributed to the development and function of the root system. Total root length and total roots number were also greater than those of the parents. Also, it was found that F1 hybrid surpassed parents in the total root length, number. of root per plant. As a result, the root system of F1 hybrids was not only greater in volume, but also longer in length. Additionally, root to shoot ratio showed higher values than that of parents. These results are in line with those mentioned by Gomez and Rangasamy (2003) reported that the parents PMK 1, Karumkuruvai and Chandaikar and the hybrids PMK $1 \mathrm{x}$ IR 64, Poongar x MDU 5, Karumkuruvai $x$ ADT 43 were the most promising for studied root traits. The hybrids PMK $1 \times$ IR 64, Poongar x MDU 5, Karumkuruvai $\times$ ADT 43 had high per se performance, significant standard heterosis were detected studied traits. Moreover, Abd-Allah (2004) reported that, the most desirable heterosis as deviation from better-parent were obtained from the crosses Giza 177 x Moroberekan and IET $1444 \times$ Moroberekan for root length, root volume, root: shoot ratio, no. of root xylem vessels number. The scored useful heterosis over mid and better parent for some root characters i.e., root length, root number, root volume, root fresh weight, root dry weight and root/shoot ratio using four rice genotypes in sixpopulation design, Abd El-Lateef et al. (2006).

\section{General combining ability of the F1 parents}

Theoretically, an estimate of GCA effect of a parent depends upon the group of other parents of which it was crossed with, (Abdalla, 2000)

\subsection{General combining ability of root characters}

Estimates of general combining ability (GCA) effects of root characters for parental genotypes are presented in table (7). Data of (GCA) estimates for the studied line parents for root characters prove that, under normal and stress conditions, signficant GCV estimates were recorded for all the studied traits except the parents Giza 177 for average root volume per plant and the parent Giza 178 for root to shoot ratio under normal condition and Giza 177 for average number of roots per plant for number of roots per plant. Moreover, under drought stress, the following parental genotypes showed negative significant GCA estemates, GZ350-20-10 and Sakha 101 for average roots volume, Azucena, GZ350-20-10 and Sakha 101 for root to shoot ratio, IET 1444, GZ350-20-10 and Sakha 101 for maximum root length and GZ350-20-10 and Sakha 101 for average root number.

\subsection{General combining ability of yield characters}

Generally, data of general combinning ability of the studied parents for yield and yield components characters Table (8) demostrate that under normal and stress conditions, signficant GCV estimates were recorded for all the studied traits except the parents Azucena and IET 1444 for average panicle length and the parent IET 1444 and Sakha 101 for average number of panicles per plant, under normal condition and Sakha 101 and Giza 178 for thousand grain weight, Azucena for average grain yield per plant, under drought stress condition only. 
J. Plant Production, Mansoura Univ., Vol. 4 (1), January, 2013

7-8 
In addition, under drought stress, the following parental genotypes showed negative significant GCA estemates for yield characters, IRAT 170, GZ35020-10 and Giza 178 for average panicle length, IRAT 170, GZ350-20-10 Giza 177 and Sakha 101 for average root number per plant, IET 1444, GZ350-20-10 and Sakha 101 for thousand grain weight, for average sterility percentage, GZ350-20-10, Giza 177 and Sakha 101 for average grain yield per plant and GZ350-20-10 for grain index.

\subsection{General combining ability of physiological characters}

As seen in Table (9) data of (GCA) exhibit that, under normal and stress conditions, signficant GCV estimates were recorded for all the studied traits except the parents IRAT 170, Giza 177, Giza 178 and Sakha 101 for average relative water content. The following parents, under drought stress condition showed positive significant general combining ability Moroberekan, Azucena, IRAT 170, Giza 177 for average flag leaf area, Moroberekan, Azucena, IRAT 170, Giza 177, Giza 178 for average chlorophyll content, Moroberekan, Azucena, IET 1444 and Giza 178 for average nitrogen content, Moroberekan, IET 1444, IRAT 170 and Giza 178 for average potassium content and the parents Moroberekan and IET 1444 for relative water content. Reversely, under drought stress, the following parental genotypes showed negative significant GCA estemates for physiological characters, IET 1444, GZ350-20-10, Giza 178 and Sakha 101 for average flag leaf area, IET 1444, GZ350-20-10 and Sakha 101 for average chlorophyll content, IRAT 170, GZ350-20-10, Giza 177 and Sakha 101 for average nitrogen content, Azucena, GZ350-20-10, Giza 177 and Sakha 101for average potassium content and Azucena, GZ350-20-10 and Giza 177 for relative water content.

\section{Specific combining ability of F1 crosses}

\subsection{Specific combining ability of root characters}

Data of spesific combinning ability (SCA) of the fiffteen F1 crosses (Table.10) demonstrate that, under normal and stress conditions, signficant SCV estimates were recorded for all the studied traits except the crosses Azucena x Giza177, Azucena x Giza178, Azucena x Sakha101, IET 1444 x Giza178, IRAT 170 x Giza177, GZ350-20-10x Giza177, GZ350-20-10x Giza178 and GZ350-20-10x Sakha101for average root volume, Azucena $x$ Giza177, Azucena x Giza178, Azucena x Sakha101, IET 1444 x Giza177 and GZ350-20-10x Sakha101 for root to shoot ratio, Moroberekanx Giza178, Azucena x Sakha101 and GZ350-20-10 x Giza177 for maximum root length, Moroberekan x Sakha101, Azucena x Giza177 and GZ350-20-10 x Giza177 under drought stress condition and finally for average number of tillers per plant with the crosses Moroberekan x Giza178, Azucena x Giza177, Azucena x Giza178, Azucena x Sakha101, IET 1444 x Giza177, IRAT 170 x Giza177, IRAT 170 x Giza178, IRAT 170 x Sakha101, GZ350-20-10 x Giza178 and GZ350-20-10 x Sakha101. 
J. Plant Production, Mansoura Univ., Vol. 4 (1), January, 2013

$9-10$ 
Negative SCA estimates were detected with all the studied genotypes. These negative estimatesas for average root volume were with the F1combiners; Moroberekan x Giza178, Moroberekan x Sakha101 and IRAT $170 \times$ Sakha101. For average root to shoot ratio; Moroberekan x Giza178, Moroberekan xSakha101, Azucena x Giza177, Azucena x Sakha101, IET 1444 x Giza177, IIET 1444 x Giza178, IRAT 170 x Sakha101, GZ350-20-10 x Giza177 and GZ350-20-10 x Giza178 for maximum root length; Moroberekan x Sakha101, Azucena x Giza177, IET 1444 x Giza177, IIET 1444 x Giza178, IRAT 170 x Giza178, IRAT 170 x Sakha101 and GZ350-20-10 x Sakha101?. Finally, for average root number; Moroberekan x Sakha101, IET $1444 \times$ Giza178 and GZ350-20-10 x Giza177.

\subsection{Specific combining ability of yield and yield component}

Estimates of spesific combining ability (SCA) estimates (Table,11) of the studied genotypes for yield and yield components characters proved that, under normal condition signficant (SCV) estimates were recorded for all the studied traits except the crosses Moroberekan x Giza177, Moroberekan x Giza178, Moroberekan x Sakha101, Azucena x Giza177, Azucena x Giza178, Azucena x Sakha101 and GZ350-20-10 x Giza177 for average panicle length; Moroberekan x Giza177, Moroberekan x Giza178, Azucena x Giza178, IET 1444 x Giza178, IRAT 170 x Giza178 and GZ350-20-10 x Giza178 for average number of panicles per plant and Moroberekan $x$ Giza177, Moroberekan x Giza178, Moroberekan x Sakha101, Azucena x Giza177, Azucena x Giza178, Azucena x Sakha101, IET 1444 x Giza177, IIET 1444 x Giza178, IRAT 170 x Giza178, GZ350-20-10 x Giza177, GZ35020-10 x Giza178 and GZ350-20-10 x Sakha101 for thousand grain weight; Moroberekan x Giza177, Moroberekan x Giza178, Azucena x Giza177, Azucena x Giza178, Azucena x Sakha101, IET 1444 x Giza178, IRAT 170 x Giza178, GZ350-20-10 x Giza178 and GZ350-20-10 x Sakha101 for average grain yield per plant, Azucena x Giza177, Azucena x Giza178, Azucena $x$ Sakha101, IRAT 170 x Giza178, IRAT 170 x Sakha101 and GZ350-20-10 x Giza178 and GZ350-20-10 x Sakha101 for average harvest index. However, under drought stress, the following genotypes showed insignificant (SCA) estemates for yield characters, Moroberekan x Giza178 and GZ350-20-10 x Giza177 for average panicle length and for average number of panicles per plant, Moroberekan x Giza177, Azucena x Giza177, Azucena x Giza178, Azucena x Sakha101, IET 1444 x Giza177, IET 1444 x Sakha101, IRAT 170 x Giza177, IRAT 170 x Sakha101 and GZ350-20-10 x Sakha101 for thousand grain weight; Azucena x Giza178, IRAT $170 \times$ Giza177, IRAT $170 \times$ Giza178, IRAT $170 \times$ Sakha101 and GZ350-20-10 x Giza178 for average sterility percentage, Moroberekan x Sakha101, Azucena x Giza177, IET 1444 $x$ Giza178 and IRAT 170 x Sakha101 for average grain yield per plant and Moroberekan x Giza178, Azucena x Giza177, Azucena x Giza178, Azucena x Sakha101, IET 1444 x Giza177, IIET 1444 x Giza178, IET 1444 x Sakha101 and IRAT $170 \times$ Giza177 for average grain index. 
J. Plant Production, Mansoura Univ., Vol. 4 (1), January, 2013 


\subsection{Specific combining ability of physiological characters}

Generally, data of spesific combinning ability (SCA) prove that, under normal and stress conditions, signficant SCV estimates were recorded for all the studied traits except the Crosses IRAT 170, Giza 177, Giza 178 and Sakha 101 for average relative water content. The following crosses, under drought stress condition showed positive significant general combining ability Moroberekan, Azucena, IRAT 170, Giza 177 for average flag leaf area; Moroberekan, Azucena, IRAT 170, Giza 177, Giza 178 for average chlorophyll content; Moroberekan, Azucena, IET 1444 and Giza 178 for average nitrogen content; Moroberekan, IET 1444, IRAT 170 and Giza 178 for average potassium content and the crosess; Moroberekan and IET 1444 for relative water content. Reversely, under drought stress, the following genotypes showed negative significant SCA estemates for physiological characters, IET 1444, GZ350-20-10, Giza 178 and Sakha 101 for average flag leaf area; IET 1444, GZ350-20-10 and Sakha 101 for average chlorophyll content; IRAT 170, GZ350-20-10, Giza 177 and Sakha 101 for average nitrogen content; Azucena, GZ350-20-10, Giza 177 and Sakha 101 for average potassium content and Azucena, GZ350-20-10 and Giza 177 for relative water content.

The above mention results indicated the importance of SCA for choosing the most favorable combiners under drought stress. The most common crosses for the studied characters were IET $1444 \times$ Sakha 101, IRAT $170 \times$ Giza177 and IRAT $170 \times$ Sakha 101. These results are in harmony with those reported by Sheng et al. (2005) they reported that drought at tillering stage enhanced the water use efficiency (WUE) of rice plant significantly in the course of and after treatment. The differences in yield and rice quality between rice cultivars in various water saving treatments were significant or highly significant. Moreover, Aidy et al. (2006) reported that Sakha 101 and the line GZ 6296-21-1-2-1-1 were the best general combiners for the physiological traits. Additive gene action played the major role in the inheritance of most of the studied traits. While, Manickavelu et al. (2006) reported that relative water content, leaf rolling, and leaf drying were governed by additive gene action; and mass selection, progeny selection and pedigree breeding can be used to improve these traits. Non-additive gene action was observed for the drought recovery rate. Moreover, Sedeek (2006) mentioned that both general and specific combining ability variances were highly significant for all characters. The additive and additive $x$ additive types of gene action were of great importance in the inheritance of studied characters. As well, Sibounheuanga et al. (2006) stated that the reduced in RWC could influence by sever stress condition and caused in maintenance of plant water relations under water deficit. 


\section{REFERENCES}

Abd-Allah, A.A. (2000). Breeding studies on rice (Oryza sativa L.). Ph.D. Thesis, Fac. Agric. Menoufiya Univ., Shibin El-Kom, Egypt.

Abd-Allah, A.A. ( 2004). A breeding study on drought tolerance in rice (Oryza sativa L.). Egyptian jou. Of agri. res. 82(1): 149-165.

Ali-Dib, T.; P. H.Monneveux; J. L. Araus (1990). Breeding durum wheat for drought tolerance. Analytical, synthetical approaches and their connection. In. Wheat breeding, prospects and future approaches. Bulgarian Agricultural Academy, Bulgaria, pp. 224-240.

Abd El-Lateef, A.S.; A.B. El-Abd and A.A. Abdalla (2006). Genetic studies of rice root characters related to drought tolerance. The first field Crops Conference, program and abstracts, 22-24 August (2006), Giza, Egypt,.

Aidy I.R., Abd El-Kareem M.Z., Glelah A.H., El-shreaf E.M. and Sedeek S.E. 2006. Combining ability and heterosis for yield and some physiological traits in rice (Oryza sativa L.). The First Field Crops Conference, (ARC), Egypt.

Barrs, H.D. and P.E.Weatherly ( 1962). Aust. J. Biol. Sci.15, 413-428.

Cottenie, A.M.; L.Verloo; G. V. Kiekens; and R. Camerlynk (1982). Chemical Analysis of Plants and Soils. PP 44-45.

De Datta, S. K.; J. A.Malabuyoc; E. L. Aragon (1988) A field screening technique for evaluating rice germplasm for drought tolerance during the vegetative stage.Field Crops Res., 19:123-134.

El-Mowafi, H.F. (2001). Combining ability analysis for some cytoplasmic male sterile and restorer rice lines under Egyptian conditions. Egypt. J. Appl. Sci. 16(2): 25-51.

El-Mowafi, H.F. and A.A. Abou Shousha (2003). Combining ability and heterosis analysis of divers CMS lines in hybrid rice. J. Agric. Res. Tanta Univ. 29(1): 106-127.

El-Mowafi, H.F. and A.H. Abd El-Hadi (2005). Studies on heterosis of some maintainer and restorer lines for cytoplasmic male sterile system in hybrid rice. Egyptian J. Agric. Res., 83(5A): 169-182.

Fahmi, A.I.; I.R. Aidy; H.H. Nagaty and M.M. El-Malky (2004). Combining ability and relationship among some Egyptian and exotic rice varieties. The International Conference on Advanced Rice Research. Egypt.

Hammoud, S. A. (2004). Inheritance of some quantitative characters in rice (Oryza sativa L.). Ph.D. Thesis, Fac. Agric., Menoufiya University, Shibin El-Kom, Egypt.

IRRI (International Rice Research Institute), (1996). Rice Almanac, 3rd Edition. (Gramene Reference ID 8379).

Panse, V.G. and P. V. Sukhatme (1957). Statistical Methods for A gricultural Workers. Indian Council of Agric. Res. New Delhi, India.

Reddy, C.D.; Y.S. Nerkar and G.D. Lakshmi (1991). Heterosis and inbreeding depression for grain size and yield in rice (Oryza sativa $L$.) under direct seeding. Indian J. Agric. Sci. 61: 416-419. 
Researcher at RRTC (2012). The National Rice Research and Development Program Workshop. RRTC., ARC., Egypt.

Ramalingam, J.; N. Nadarajan; C. Vanniarajan and P. Rangasmy (1994). Heterosis in rice hybrids. Indian Journal of Genetics and Plant Breeding 54(4): 371-375.

Sedeek, S.E.M. (2006). Breeding studies on rice. Ph.D. Thesis, Faculty of Agriculture, Kafr El-Sheikh, Tanta University, Egypt.

Yoshida, S. (1981). Fundamentals of rice crop science. Los Baños (Philippines):International Rice Research Institute., 269 p.

Yogameenashi, P.; N. Nadarajan and A. Sheeba (2003). Evaluation of varieties and land races for drought tolerance in rice (Oryza sativa L.). Indian J. Genet. 63(4): 299-303.

Barrs H.D. and Weatherly P.E. 1962. A re-examination of the relative turgidity technique for estimating water deficits in leaves Aust. J. Biol. Sci.15, 413-428.

Begg J. E. 1980. Adaptation of Plants to Water and High Temperature Stress (eds Turner, N. C. and Kramer, P. J.), Wiley, New York, pp. 33-42.

Blum A. 2002. Drought stress and its impact. plantstress.com /Articles/index.asp. Butany W.T. 1961. Mass emasculation in rice. Intern. Rice Com. News letter 9: 9-13.

Jodon N.E. 1938. Experiments on artificial hybridization of rice. J.Mer. Soc. Agron. 30:249-305.

Levitt J. 1972. Responses of Plants to Environmental Stresses, Academic Press, New York.

O'Toole J.C. and Moya T. B. 1978. Genotypic variation in maintenance of leaf water potential in rice. Crop Sci., 18, 873-876.

O'Toole J.C. and De Datta S.K. 1986. Drought resistance in rainfed lowland rice, in: Progress in Rainfed Lowland Rice, International Rice Research Institute, Makati City, Philippines, pp. 145-158.

O'Toole J.C. 2004. Rice and water: the final frontier. First International Conference on Rice for the Future, 31August-2 Sept. 2004, Bangkok, Thailand.

Young J. and Virmani S.S. 1990. Heterosis in rice over environments. Euphytica 51: 87-93.

Zhong L.Y., Jian H., Chang Y.J., Jian Z.Z. and Sen Z.Q.2006 Morphological and anatomic traits in drought-resistant rice root. Journal of Yangzhou University, Agricultural and Life Sciences Edition. 24(4): 58-61. 


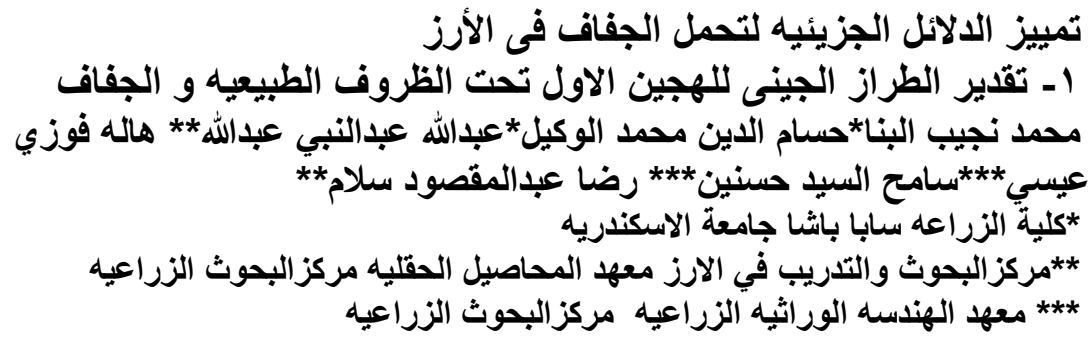

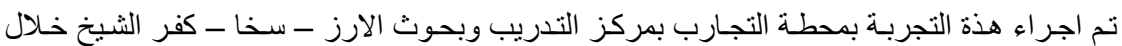

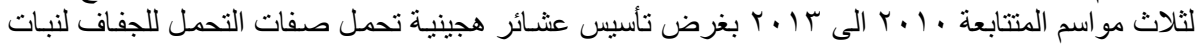

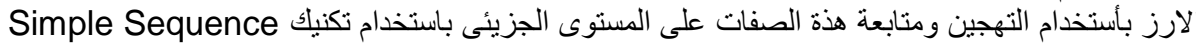

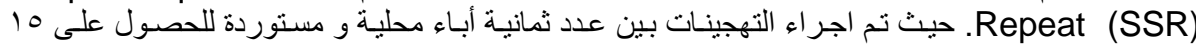

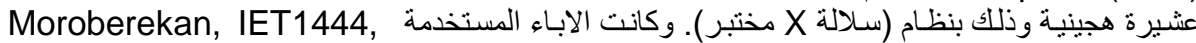
خلال Azucena, IRAT170, GZ530-20-10, Giza177, Giza 178 and Sakha101

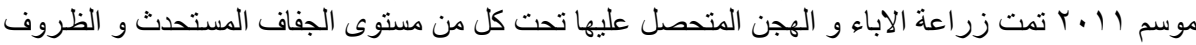

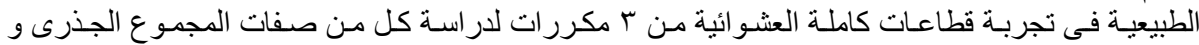
المحصول بالاضافة الى بعض التقاع التقبير ات الفسيولوجية.

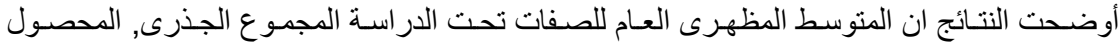

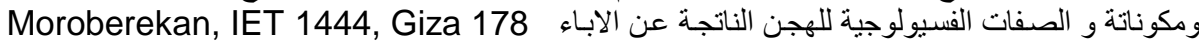
Moroberekan x Giza177 and IET و الهجن الداخلة فيهم وخاصنة الهجن الابهن 101

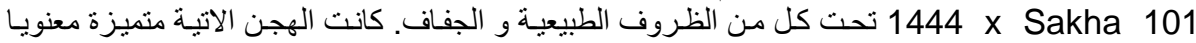

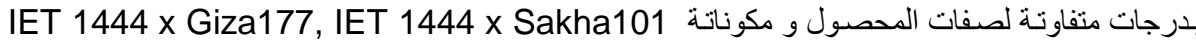

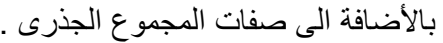

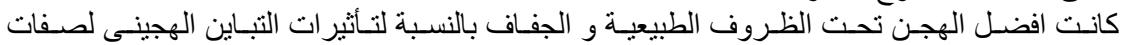

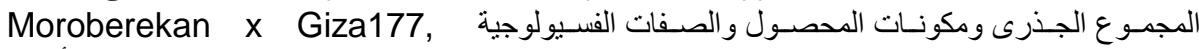
Moroberekan x Sakha101, IET 1444 x Giza178, IET 1444 x Sakha101

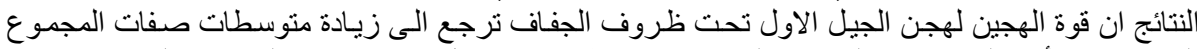

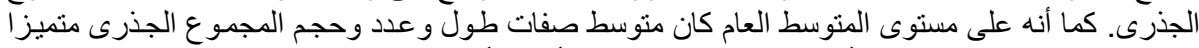

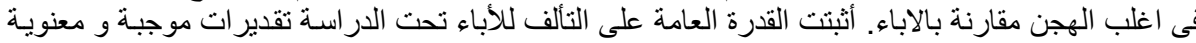

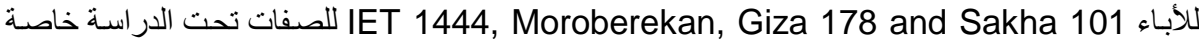

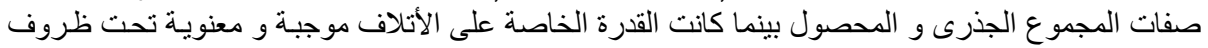

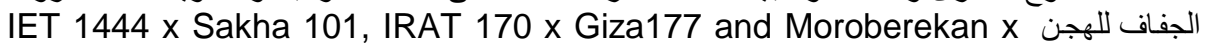

كلية الزراعة - جامعة المنصورة

قام بتحكيم هذا البحث
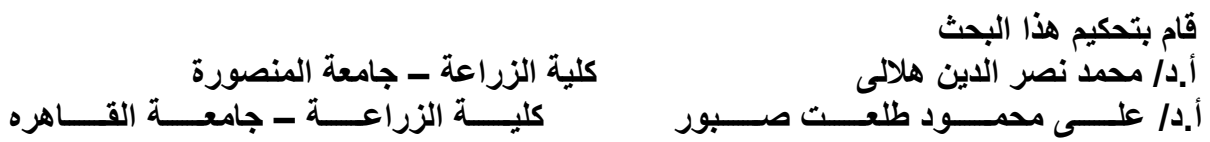
El Banna, M. N. et al. 
Table (2): Mean performances of yield and yield components characters for the studied eight parents and fifteen F1 crosses as affected by normal and drought stress and their combined data

\begin{tabular}{|c|c|c|c|c|c|c|c|c|c|c|c|c|c|c|c|c|c|c|c|}
\hline \multirow{2}{*}{\begin{tabular}{|l|} 
Characters \\
Genotypes \\
\end{tabular}} & \multicolumn{3}{|c|}{ Panicle length } & \multicolumn{3}{|c|}{ Number of tillers/plant } & \multicolumn{3}{|c|}{ 1000- grain weight } & \multicolumn{3}{|c|}{ Sterility \% } & \multicolumn{3}{|c|}{ Grain yield/plant } & \multicolumn{3}{|c|}{ Harvest index } & \multirow[t]{2}{*}{ DS\% } \\
\hline & $\mathbf{N}$ & $\mathbf{S}$ & C & $\mathbf{N}$ & $\mathbf{S}$ & C & $\mathbf{N}$ & $\mathbf{S}$ & C & $\mathbf{N}$ & $\mathbf{s}$ & C & $\mathbf{N}$ & $\mathbf{S}$ & C & $\mathbf{N}$ & $\mathbf{S}$ & C & \\
\hline P1 & 28.63 & 25.81 & 27.22 & & 11.18 & & & 3.56 & & 7.70 & & 10.13 & 25.81 & 21.87 & & 0.26 & 0.26 & & 0.15 \\
\hline & & & & & & & & & & & & & & & & & & & \\
\hline & & & & & & & & & & & & & & & & & 27 & & \\
\hline P4 & 27.39 & 24.39 & 25.89 & & & & & & & 55 & & 7.51 & & 21.39 & & & 25 & & \\
\hline & & & & & & & & & & & & & & & & & 27 & & \\
\hline & & & & & & & & & & & & & & & & & 29 & & \\
\hline & 25.2 & & 24.11 & & & & & & & 67 & & 6.63 & & 27.58 & & & 32 & & 31 \\
\hline & 24.34 & 20.67 & 22.51 & & & & & & & 39 & 2.07 & 8.73 & & & & & 33 & & .52 \\
\hline & 27.5 & & & & & & & & & 1 & & 35 & & & & & 27 & & \\
\hline & & & 26.71 & & & & & & & & & & & & & & 29 & & \\
\hline & 28.9 & 2 & 28.21 & 2 & & & & 3.27 & & 40 & 11.08 & 10.24 & 2.94 & 29.18 & & & 32 & & \\
\hline & & & 26.05 & & & & & & & 38 & & 9.27 & & & & & 28 & & \\
\hline & & & 24.31 & & & & & & & 24 & & 8.12 & & 30. & & & 29 & & 28 \\
\hline & 26.4 & 24.5 & 25.50 & & & & & & & 62 & & 9.66 & & & & & 29 & & 37 \\
\hline & 25.5 & 24. & 24.93 & & & & & 2. & & 7.92 & 51 & 8.72 & & 25.90 & & & 30 & & 28 \\
\hline & & & & & & & & & & & & & & & & & 29 & & \\
\hline & & 26. & 27.02 & & & & & & & & & 8.0 & & & & & 30 & & 0.27 \\
\hline XP6 & 27.18 & 25.42 & 26.30 & 14.28 & 11.3 & & 3.7 & 3.54 & 3.64 & 9.92 & 11.98 & 10.95 & 36.89 & 31.12 & 01 & 3 & 29 & .31 & 0.15 \\
\hline & & & 24.61 & & & & & & & & & & & 25.18 & & & 28 & & .36 \\
\hline & & & & & & & & & & & & & & & & & 30 & & \\
\hline & & 2.1 & 3.52 & & & & & & & & & & & 23. & & & 28 & & 32 \\
\hline & 22.66 & 22.91 & 22.79 & 1 & 11.1 & & & 2.43 & 2.67 & 9.64 & 11.14 & 10.39 & 36.66 & 22.03 & 29.35 & & 0.28 & & 40 \\
\hline & & & & 12.82 & & & & 2.38 & 2.64 & 9.78 & & .76 & 5.05 & 20.65 & 27.85 & 32 & 0.22 & 0.27 & 41 \\
\hline & & & & & & & & & & & & & & & & & & & \\
\hline
\end{tabular}


Table (4): The estimated heterosis percentages over mid parent (MP) and their significance for yield characters of the studied fifteen F1 crosses grown under normal, drought stress and their combined data

\begin{tabular}{|c|c|c|c|c|c|c|c|c|c|c|c|c|c|c|c|c|c|c|c|}
\hline \multirow{2}{*}{ Genotypes } & \multicolumn{3}{|c|}{ Sterility \% } & \multicolumn{3}{|c|}{ Grain yield/plant, $\mathbf{g}$} & \multicolumn{3}{|c|}{ Harvest index } & \multicolumn{3}{|c|}{ Panicle length } & \multicolumn{6}{|c|}{ Number of panicles/plant 1000 -grain weight } & \multirow{2}{*}{$\begin{array}{c}\text { DS } \% \\
\mathbf{N}\end{array}$} \\
\hline & $\mathbf{N}$ & $\mathbf{s}$ & C & $\mathbf{N}$ & $\mathbf{s}$ & C & $\mathbf{N}$ & $\mathbf{S}$ & C & $\mathbf{N}$ & $\mathbf{S}$ & C & $\mathbf{N}$ & $\mathbf{S}$ & C & $\mathbf{N}$ & $\mathrm{s}$ & $\mathbf{c}$ & \\
\hline 6 & $13.76^{\star}$ & $4.11^{*}$ & & & $34.13^{\star}$ & $28.04^{*}$ & & $8.68^{*}$ & $-12.01^{*}$ & $7.42^{*}$ & $4.53^{*}$ & $6.04^{*}$ & & $11.27^{*}$ & $18.14^{\star}$ & $5.94 \mathrm{~ns}$ & $16.65^{\star}$ & $10.97^{\star}$ & $-39.80^{*}$ \\
\hline & & & & & & & & & & & & & & & & & & & \\
\hline & & $20^{*}$ & $3^{*}$ & & $.85^{*}$ & & & & $9.93^{*}$ & & $10.58^{\star}$ & & & & & & $0.20^{*}$ & $7.87^{*}$ & \\
\hline & $78^{*}$ & 50ns & רs & & $88^{*}$ & & & $57 \mathrm{~ns}$ & $-9.57^{\star}$ & & & & & & & & $16.97^{\star}$ & $2.76^{*}$ & \\
\hline & & $2 \mathrm{~ns}$ & 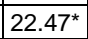 & & & & & & -9.3 & & $-0.79 n s$ & & & & & & $0.23^{*}$ & $6.84^{*}$ & \\
\hline & & 6 ns & .6 & $41^{\star}$ & .9 & .0 & & J.81 & 1. & & $23^{*}$ & 75 & & 4.6 & $16.10^{*}$ & $5.74 \mathrm{~ns}$ & $15.40^{*}$ & $0.35^{*}$ & \\
\hline & & & & & * & $.88^{\star}$ & & & & & $83^{*}$ & & & & & $46 n$ & $16 \mathrm{~ns}$ & ns & \\
\hline & & $.54^{\star}$ & $-7.58^{*}$ & & $3^{*}$ & $20.79^{*}$ & & $-8.87^{\star}$ & $-10.72^{*}$ & & -0.83 & $47 n s$ & & & & $12.83^{*}$ & $2.02 \mathrm{~ns}$ & $7.68^{\star}$ & \\
\hline & & $168^{*}$ & $.13^{*}$ & $65^{*}$ & $46.54^{\star}$ & $32.38^{*}$ & & $-9.23^{*}$ & $-9.91^{*}$ & $3.56^{*}$ & $15.34^{\star}$ & 17.00 & & & $9^{*}$ & $11.04^{*}$ & $0.22 \mathrm{~ns}$ & $5.97^{*}$ & \\
\hline & & $43^{*}$ & $.74^{\star}$ & $73^{*}$ & $.59^{*}$ & $33.14^{*}$ & & $1.03 \mathrm{~ns}$ & $-9.10^{*}$ & 4.89 & $8.07^{\star}$ & 6 & & & $14.17^{\star}$ & $18.26^{*}$ & $19.81^{*}$ & $19.01^{*}$ & 15 \\
\hline & & $.71^{\star}$ & $.95^{\star}$ & $.72^{\star}$ & $2.33 \mathrm{~ns}$ & $111.75^{\star}$ & & $-12.18^{*}$ & -12.32 & $-3.37^{\star}$ & $2.60 \mathrm{~ns}$ & $-3.00^{*}$ & & & $-3.05 \mathrm{~ns}$ & $17.44^{\star}$ & $20.94^{*}$ & $19.15^{\star}$ & \\
\hline & & & & & & & & $-9.47^{\star}$ & & & $-5.45^{*}$ & & & & & & $19.76^{\star}$ & $4.37^{*}$ & \\
\hline & & $38^{\star}$ & $48^{\star}$ & $57 \mathrm{~ns}$ & $81^{*}$ & $4.47 \mathrm{~ns}$ & & $-3.91 \mathrm{~ns}$ & -12. & $0.08 \mathrm{~ns}$ & $-0.76 \mathrm{~ns}$ & -0. & & & $55^{*}$ & $5.80 \mathrm{~ns}$ & $-7.12^{*}$ & $0.34 \mathrm{~ns}$ & \\
\hline XX? & $6.31^{*}$ & $29.75^{*}$ & $.75^{*}$ & $56 \mathrm{~ns}$ & $-12.11^{*}$ & \begin{tabular}{|l|} 
\\
\end{tabular} & $56^{*}$ & $-14.94^{\star}$ & $-15.83^{\star}$ & $-8.09^{*}$ & $-3.98^{*}$ & $\mid-6.07^{*}$ & & & $-18.18^{*}$ & $17.55^{*}$ & $6.92^{*}$ & $12.45^{\star}$ & $3.62^{*}$ \\
\hline & & $5.08 \mathrm{~ns}$ & $23.25^{*}$ & $-6.69^{*}$ & $-3.31 \mathrm{~ns}$ & $-5.47^{\star}$ & & $-33.71^{*}$ & $-27.43^{*}$ & $3.77^{\star}$ & $1.76 \mathrm{~ns}$ & 2.77 & & & -30 . & $7.69^{\star}$ & $-0.57 \mathrm{~ns}$ & $3.79 \mathrm{~ns}$ & \\
\hline & 0.73 & 0.68 & \begin{tabular}{|l|}
0.47 \\
\end{tabular} & 2.29 & & 1.34 & & 2.42 & \begin{tabular}{|l|}
1.80 \\
\end{tabular} & 0.85 & 0.93 & & & & & 1.97 & 1.44 & 1.37 & 0.07 \\
\hline
\end{tabular}


J. Plant Production, Mansoura Univ., Vol. 4 (1), January, 2013

Table (6): General combining ability (GCA) estimates of yield components characters (5 lines and 3 tester) parents genotypes grown under normal and drought stress and their combined data

\begin{tabular}{|c|c|c|c|c|c|c|c|c|c|c|c|c|c|c|c|c|c|c|}
\hline \multirow{2}{*}{\begin{tabular}{|l|} 
Character \\
Genotype
\end{tabular}} & \multicolumn{3}{|c|}{ Panicle length } & \multicolumn{3}{|c|}{$\begin{array}{c}\text { Number of } \\
\text { panicles/plant }\end{array}$} & \multicolumn{3}{|c|}{1000 -grain weight } & \multicolumn{3}{|c|}{ Sterility \% } & \multicolumn{3}{|c|}{ Grain yield/plant } & \multicolumn{3}{|c|}{ Harvest index } \\
\hline & $\mathbf{N}$ & $\mathbf{S}$ & C & $\mathbf{N}$ & $\mathbf{S}$ & C & $\mathbf{N}$ & $\mathbf{S}$ & C & $\mathbf{N}$ & $\mathbf{S}$ & C & $\mathbf{N}$ & $\mathbf{S}$ & C & $\mathbf{N}$ & $\mathbf{s}$ & C \\
\hline P1 & $2.40^{*}$ & $1.81^{*}$ & $2.10^{*}$ & $4.12^{*}$ & $0.86^{*}$ & $2.49^{*}$ & $3.41^{*}$ & $4.50^{*}$ & $3.95^{*}$ & $-0.84^{*}$ & $-0.46^{*}$ & $-0.65^{\star}$ & $2.40^{*}$ & $2.50^{*}$ & $2.45^{*}$ & $0.05 \mathrm{~ns}$ & $0.45 \mathrm{~ns}$ & $0.25 \mathrm{~ns}$ \\
\hline $\mathbf{P 2}$ & $-0.1 \mathrm{~ns}$ & $0.26^{*}$ & $0.07 n$ & $0.31^{*}$ & $-0.31^{*}$ & $0.00 \mathrm{~ns}$ & $1.89^{*}$ & $4.13^{*}$ & $3.01^{*}$ & $-0.44^{*}$ & $-0.29^{\star}$ & $-0.36^{*}$ & $1.04^{*}$ & $-0.2 n s$ & $0.41^{*}$ & $0.90^{*}$ & $0.57^{*}$ & $0.74^{*}$ \\
\hline $\mathbf{P 3}$ & $-0.05 n s$ & $-0.1 \mathrm{~ns}$ & $-0.08 \mathrm{~s}$ & $-0.1 \mathrm{~ns}$ & $1.72^{\star}$ & $0.81^{*}$ & $-4.56^{\star}$ & $-7.05^{\star}$ & $-5.80^{*}$ & $-1.32^{*}$ & $-2.20^{*}$ & $-1.76^{*}$ & $1.48^{*}$ & $2.39^{*}$ & $1.93^{*}$ & $1.08^{*}$ & $1.18^{*}$ & $1.13^{\star}$ \\
\hline P4 & $-0.32^{*}$ & $-0.58^{*}$ & $-0.45^{*}$ & $-0.80^{\star}$ & $0.68^{*}$ & $-0.06^{\star}$ & $2.83^{*}$ & $4.63^{*}$ & $3.73^{*}$ & $0.69^{*}$ & $1.09^{*}$ & $0.89^{*}$ & $-1.36^{*}$ & $0.58^{*}$ & $-0.39^{*}$ & $-0.1 \mathrm{~ns}$ & $0.52^{\star}$ & $0.19 \mathrm{~ns}$ \\
\hline P5 & $-1.90^{*}$ & $-1.38^{\star}$ & $-1.64^{*}$ & $-3.51^{*}$ & $-2.95^{*}$ & $-3.24^{*}$ & $-3.56^{*}$ & $-6.21^{*}$ & $-4.89^{*}$ & $1.90^{\star}$ & $1.86^{*}$ & $1.88^{*}$ & $-3.56^{*}$ & $-5.25^{\star}$ & $-4.41^{*}$ & $-1.90^{*}$ & $-2.72^{*}$ & $-2.31^{*}$ \\
\hline L.S.D 5\% & 0.20 & 0.22 & 0.16 & 0.22 & 0.17 & 0.15 & 0.47 & 0.34 & 0.32 & 0.15 & 0.14 & 0.10 & 0.54 & 0.34 & 0.32 & 0.54 & 0.49 & 0.37 \\
\hline P6 & $0.38^{\star}$ & $0.32^{*}$ & $0.35^{*}$ & $-1.43^{*}$ & $-0.38^{\star}$ & $-0.91^{*}$ & $0.67^{*}$ & $0.49^{*}$ & $0.58^{*}$ & $0.37^{\star}$ & $0.63^{*}$ & $0.50^{*}$ & $-2.27^{\star}$ & $-0.69^{\star}$ & $-1.48^{*}$ & $-0.58^{\star}$ & $-0.2 n s$ & $-0.40^{*}$ \\
\hline P7 & $-0.99^{*}$ & $-0.69^{*}$ & $-0.84^{*}$ & $1.29^{\star}$ & $0.87^{*}$ & $1.08^{*}$ & $-0.52^{*}$ & $-0.1 \mathrm{~ns}$ & $-0.33^{*}$ & $-0.97^{*}$ & $-1.06^{*}$ & $-1.02^{*}$ & $1.57^{*}$ & $1.13^{*}$ & $1.35^{*}$ & $-0.53^{*}$ & $0.14 \mathrm{~ns}$ & $-0.1 \mathrm{~ns}$ \\
\hline $\mathbf{P 8}$ & $0.61^{*}$ & $0.37^{*}$ & $0.49^{\star}$ & $0.15 \mathrm{~ns}$ & $-0.49^{*}$ & $-0.17^{\star}$ & $-0.1 n s$ & $-0.34^{\star}$ & $-0.25 \mathrm{~s}$ & $0.60^{*}$ & $0.42^{*}$ & $0.51^{*}$ & $0.70^{*}$ & $-0.44^{\star}$ & $0.13 n s$ & $1.11^{*}$ & $0.08 \mathrm{~ns}$ & $0.59^{\star}$ \\
\hline L.S.D 5\% & 0.16 & 0.17 & 0.12 & 0.17 & 0.13 & 0.11 & 0.36 & 0.26 & 0.25 & 0.12 & 0.11 & 0.08 & 0.42 & 0.26 & 0.25 & 0.42 & 0.38 & 0.29 \\
\hline
\end{tabular}


Table (9), Specific combining ability (SCA) estimates of root characters for the fifteen F1 combiners grown under normal and drought stress and their combined data

\begin{tabular}{|c|c|c|c|c|c|c|c|c|c|c|c|c|c|c|c|c|c|c|}
\hline \multirow{2}{*}{ Genotypes } & \multicolumn{3}{|c|}{ Sterility \% } & \multicolumn{3}{|c|}{ Grain yield /plant, $\mathbf{g}$} & \multicolumn{3}{|c|}{ Harvest index } & \multicolumn{3}{|c|}{ Panicle length } & \multicolumn{3}{|c|}{ Number of panicles/plant } & \multicolumn{3}{|c|}{ 1000-grain weight } \\
\hline & $\mathbf{N}$ & $\mathbf{S}$ & C & $\mathbf{N}$ & $\mathbf{S}$ & 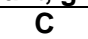 & $\mathbf{N}$ & $\mathbf{S}$ & C & $\mathbf{N}$ & $\mathrm{S}$ & C & $\mathbf{N}$ & $\mathbf{S}$ & C & $\mathbf{N}$ & $\mathbf{S}$ & C \\
\hline P1XP6 & $-0.1 \mathrm{~ns}$ & $-1.05^{*}$ & $-0.62^{*}$ & $13 \mathrm{~ns}$ & $0.67^{*}$ & $0.40^{*}$ & $-0.39 \mathrm{~ns}$ & $0.44 \mathrm{~ns}$ & $0.03 \mathrm{~ns}$ & $-1.65^{*}$ & $-1.13^{*}$ & $-1.39^{*}$ & $.59 \mathrm{~ns}$ & $-2.37^{*}$ & $-1.48^{*}$ & $0.11 \mathrm{~ns}$ & $-2.14^{*}$ & $-1.01^{*}$ \\
\hline P1XP7 & $0.2 \mathrm{~ns}$ & $0.24 \mathrm{~ns}$ & $0.2 \mathrm{~ns}$ & $0.34 \mathrm{~ns}$ & $0.18 \mathrm{~ns}$ & $0.26^{*}$ & $0.37 \mathrm{~ns}$ & $0.91^{*}$ & $0.64^{*}$ & $0.53^{*}$ & $0.26^{*}$ & $0.39^{*}$ & $-0.43 n s$ & $2.46^{*}$ & $1.02^{*}$ & $-0.51 \mathrm{~ns}$ & $-0.27 n s$ & $-0.39 n s$ \\
\hline P1XP8 & $-0.0 \mathrm{~ns}$ & $0.81^{*}$ & $0.40^{*}$ & $-0.46^{*}$ & $-0.85^{\star}$ & $-0.65^{*}$ & $0.01 \mathrm{~ns}$ & $-1.35^{*}$ & $-0.67^{*}$ & $1.12^{*}$ & $0.87^{*}$ & $1.00^{*}$ & $1.02^{*}$ & $-0.09 n s$ & $0.46 \mathrm{~ns}$ & $0.40 \mathrm{~ns}$ & $2.41^{*}$ & $1.40^{*}$ \\
\hline P2XP6 & $-0.1 \mathrm{~ns}$ & $0.97^{*}$ & $0.41^{\star}$ & $0.68^{*}$ & $1.90^{*}$ & $1.29^{*}$ & $0.24 \mathrm{~ns}$ & $0.31 \mathrm{~ns}$ & $0.27 n s$ & $-0.07 \mathrm{~ns}$ & $-0.43^{*}$ & $-0.25^{*}$ & $-0.18 n s$ & $-0.58 \mathrm{~ns}$ & $-0.38 n s$ & $-0.84 \mathrm{~ns}$ & $-0.48 n s$ & $-0.66^{*}$ \\
\hline P2XP7 & $0.1 \mathrm{~ns}$ & $-0.40^{\star}$ & $-0.1 \mathrm{~ns}$ & $-0.18 \mathrm{~ns}$ & $-0.60^{*}$ & $-0.39^{*}$ & $0.10 \mathrm{~ns}$ & $-0.28 n s$ & $-0.09 n s$ & $0.13 \mathrm{~ns}$ & $0.10 \mathrm{~ns}$ & $0.12 \mathrm{~ns}$ & $0.91 \mathrm{~ns}$ & $2.07^{\star}$ & $1.49^{\star}$ & $0.41 \mathrm{~ns}$ & $0.11 \mathrm{~ns}$ & $0.26 \mathrm{~ns}$ \\
\hline P2XP8 & $0.02 n$ & $-0.57^{*}$ & $-0.28^{*}$ & $-0.50^{*}$ & $-1.30^{*}$ & $-0.90^{*}$ & $-0.34 n s$ & $-0.03 n s$ & $-0.19 n s$ & $-0.06 \mathrm{~ns}$ & \begin{tabular}{|l|l}
$0.33^{*}$ \\
\end{tabular} & $0.13 \mathrm{~ns}$ & $73 \mathrm{~ns}$ & $-1.50^{*}$ & $-1.11^{*}$ & $0.43 \mathrm{~ns}$ & $0.37 \mathrm{~ns}$ & $0.40 \mathrm{~ns}$ \\
\hline & $-0.73^{*}$ & $-0.39^{*}$ & $-0.56^{*}$ & $-1.35^{*}$ & $-1.04^{*}$ & $-1.19^{*}$ & $-0.54 n s$ & $0.19 \mathrm{~ns}$ & $-0.18 n s$ & $0.35^{*}$ & $0.84^{\star}$ & $0.59^{*}$ & & $-3.01^{*}$ & $-2.50^{*}$ & $-0.01 \mathrm{~ns}$ & $0.19 \mathrm{~ns}$ & $0.09 \mathrm{~ns}$ \\
\hline P3XP7 & $-0.81^{*}$ & $-0.84^{*}$ & $-0.83^{*}$ & $-0.27 n s$ & $-0.57^{*}$ & $-0.42^{*}$ & $-0.53 \mathrm{~ns}$ & $-0.60^{*}$ & $-0.57^{*}$ & $-0.72^{\star}$ & $-0.24^{*}$ & $-0.48^{*}$ & $-0.72 n$ & $0.27 \mathrm{~ns}$ & $-0.23 \mathrm{~ns}$ & $-0.79 \mathrm{~ns}$ & $-0.46 n s$ & $-0.62 n s$ \\
\hline P3XP8 & $\begin{array}{ll}1.55^{\star} \\
\end{array}$ & $1.23^{*}$ & $1.39^{\star}$ & $1.62^{*}$ & $1.61^{*}$ & $1.61^{*}$ & $1.08^{*}$ & $0.42 \mathrm{~ns}$ & $0.75^{*}$ & $0.37^{\star}$ & $-0.59^{*}$ & $-0.11 \mathrm{~ns}$ & $2.72^{*}$ & $2.74^{*}$ & $2.73^{*}$ & $0.80 \mathrm{~ns}$ & $0.28 \mathrm{bs}$ & $0.54 \mathrm{~ns}$ \\
\hline P4XP6 & $1.21^{*}$ & $1.16^{*}$ & $1.18^{\star}$ & $-0.77^{*}$ & $-1.78^{*}$ & $-1.28^{*}$ & $1.47^{*}$ & $0.39 \mathrm{~ns}$ & $0.93^{*}$ & $0.33^{*}$ & $0.02 \mathrm{~ns}$ & $0.18^{*}$ & $1.70^{*}$ & $4.02^{*}$ & $2.86^{*}$ & $0.08 \mathrm{~ns}$ & $0.01 \mathrm{~ns}$ & $0.04 \mathrm{~ns}$ \\
\hline P4XP7 & $0.83^{*}$ & $0.54^{\star}$ & $0.69^{\star}$ & $0.33 \mathrm{~ns}$ & $0.58^{\star}$ & $0.45^{*}$ & $-0.57 \mathrm{~ns}$ & $-0.85^{*}$ & $-0.71^{*}$ & $-0.14 \mathrm{~ns}$ & $-0.21 \mathrm{~ns}$ & $-0.18^{*}$ & & $-3.74^{*}$ & $-1.67^{*}$ & $0.36 \mathrm{~ns}$ & $-0.87^{*}$ & $-0.25 n s$ \\
\hline P4XP8 & $-2.04^{*}$ & $-1.70^{*}$ & $-1.87^{\star}$ & $0.44^{*}$ & $1.20^{*}$ & $0.82^{*}$ & $-0.91^{*}$ & $0.47 \mathrm{~ns}$ & $-0.22 n s$ & $-0.19 n s$ & $0.19 \mathrm{~ns}$ & $-0.001 n$ & $-2.10^{*}$ & $-0.28 \mathrm{~ns}$ & $-1.19^{*}$ & $-0.44 n s$ & $0.86^{*}$ & $0.21 \mathrm{~ns}$ \\
\hline P5XP6 & $-0.1 \mathrm{~ns}$ & $-0.69^{*}$ & $-0.41^{\star}$ & $1.31^{*}$ & $0.25 \mathrm{~ns}$ & $0.78^{*}$ & $-0.79 \mathrm{~ns}$ & $-1.32^{*}$ & $-1.05^{*}$ & $1.04^{*}$ & \begin{tabular}{|l|l}
$0.70^{*}$ \\
\end{tabular} & $0.87^{\star}$ & $1.06^{*}$ & $1.93^{\star}$ & $1.50^{\star}$ & $0.66 \mathrm{~ns}$ & $2.42^{\star}$ & $1.54^{*}$ \\
\hline P5XP7 & $-0.36^{*}$ & $0.45^{*}$ & $0.05 \mathrm{~ns}$ & $\begin{array}{l}-0.21 n s \\
\end{array}$ & $0.41^{\star}$ & $0.10 \mathrm{~ns}$ & $0.62 \mathrm{~ns}$ & $0.82^{*}$ & $0.72^{*}$ & $0.20 \mathrm{~ns}$ & $0.10 \mathrm{~ns}$ & $0.14 \mathrm{~ns}$ & $-0.16 \mathrm{~ns}$ & $-1.06^{*}$ & $-0.61^{*}$ & $0.53 \mathrm{~ns}$ & $1.49^{\star}$ & $1.01^{*}$ \\
\hline & $0.49^{*}$ & $0.2 \mathrm{~ns}$ & $0.36^{*}$ & $-1.10^{*}$ & $-0.66^{*}$ & $-0.88^{*}$ & $0.16 \mathrm{~ns}$ & $0.51 \mathrm{~ns}$ & $0.33 \mathrm{~ns}$ & $-1.23^{*}$ & \begin{tabular}{|l|}
$-0.80^{*}$ \\
\end{tabular} & $-1.01^{*}$ & -0.96 & $-0.87^{*}$ & $-0.89^{*}$ & $-1.19^{*}$ & $-3.91^{*}$ & $-2.55^{*}$ \\
\hline LSD 5\% & \begin{tabular}{|l|}
0.35 \\
\end{tabular} & 0.38 & 0.28 & 0.39 & 0.29 & 0.25 & 0.81 & \begin{tabular}{|l|}
0.59 \\
\end{tabular} & \begin{tabular}{|l|}
0.56 \\
\end{tabular} & 0.26 & 0.24 & 0.17 & 0.94 & 0.59 & 0.55 & 0.94 & 0.86 & 0.64 \\
\hline
\end{tabular}

Table (10): Specific combining ability (SCA) estimates of yield characters for the fifteen F1 combiners grown under normal and drought stress and their combined data

\begin{tabular}{|c|c|c|c|c|c|c|c|c|c|c|c|c|}
\hline Characters & \multicolumn{3}{|c|}{ Root volume } & \multicolumn{3}{|c|}{ Root : shoot ratio } & \multicolumn{3}{|c|}{ Maximum root length } & \multicolumn{3}{|c|}{ Number of roots } \\
\hline Genotypes & $\mathbf{N}$ & $\mathbf{S}$ & C & $\mathbf{N}$ & $\mathbf{S}$ & C & $\mathbf{N}$ & $\mathbf{S}$ & C & $\mathbf{N}$ & $\mathbf{S}$ & $\mathrm{C}$ \\
\hline P1XP6 & $3.83^{*}$ & $3.34^{*}$ & $3.59^{*}$ & $0.02^{*}$ & $0.03^{*}$ & $0.02^{*}$ & $2.66^{*}$ & $0.58^{*}$ & $1.62^{*}$ & $6.48^{*}$ & $6.17^{*}$ & $6.33^{*}$ \\
\hline P1XP7 & $-1.89^{\star}$ & $-1.61^{\star}$ & $-1.75^{\star}$ & $-0.01^{*}$ & $-0.01^{*}$ & $-0.01^{*}$ & $0.35 \mathrm{~ns}$ & $-0.39^{*}$ & $-0.02 n s$ & $-0.01 n s$ & $-0.01 \mathrm{~ns}$ & $-0.01 \mathrm{~ns}$ \\
\hline P1XP8 & $-1.94^{*}$ & $-1.74^{\star}$ & $-1.84^{\star}$ & $-0.01^{*}$ & $-0.02^{*}$ & $-0.02^{*}$ & $-3.01^{*}$ & $-0.19 n s$ & $-1.60^{*}$ & $-6.48^{*}$ & $-6.16^{*}$ & $-6.32^{*}$ \\
\hline P2XP6 & $-0.23 n s$ & $-0.18 n s$ & $-0.21 \mathrm{~ns}$ & $0.01 \mathrm{~ns}$ & $-0.02^{*}$ & $-0.01^{*}$ & $-1.84^{*}$ & $-0.02 n s$ & $-0.93^{*}$ & $-1.21 \mathrm{~ns}$ & $-1.15 n s$ & $-1.18 n s$ \\
\hline P2XP7 & $0.52 \mathrm{~ns}$ & $0.48 \mathrm{~ns}$ & $0.50 \mathrm{~ns}$ & $-0.001 \mathrm{~ns}$ & $0.04^{*}$ & $0.02^{*}$ & $1.63^{*}$ & $0.90^{*}$ & $1.26^{*}$ & $2.11 \mathrm{~ns}$ & $2.01 \mathrm{~ns}$ & $2.06 \mathrm{~ns}$ \\
\hline P2XP8 & $-0.29 n s$ & $-0.31 n s$ & $-0.30 n s$ & $-0.01 \mathrm{~ns}$ & $-0.02^{*}$ & $-0.01^{*}$ & $0.21 \mathrm{~ns}$ & $-0.87^{*}$ & $-0.33 n s$ & $-0.90 n s$ & $-0.85 n s$ & $-0.87 n s$ \\
\hline P3XP6 & $-3.30^{*}$ & $-2.82^{*}$ & $-3.06^{*}$ & $-0.002 n s$ & $-0.02^{*}$ & $-0.01^{*}$ & $-4.92^{\star}$ & $1.06^{*}$ & $-1.93^{*}$ & $-3.29 n s$ & $-3.13 n s$ & $-3.21 \mathrm{~ns}$ \\
\hline P3XP7 & $-0.61 n s$ & $-0.50 \mathrm{~ns}$ & $-0.56 n s$ & $-0.04^{*}$ & $-0.05^{*}$ & $-0.04^{\star}$ & $-1.95^{\star}$ & $-3.58^{\star}$ & $-2.76^{\star}$ & $-7.36^{*}$ & $-7.00^{*}$ & $-7.18^{\star}$ \\
\hline P3XP8 & $3.91^{*}$ & $3.32^{*}$ & $3.62^{*}$ & $0.04^{*}$ & $0.07^{\star}$ & $0.05^{\star}$ & $6.87^{\star}$ & $2.52^{*}$ & $4.69^{*}$ & $10.65^{\star}$ & $10.13^{\star}$ & $10.39^{*}$ \\
\hline P4XP6 & $0.53 \mathrm{~ns}$ & $0.49 \mathrm{~ns}$ & $0.50 \mathrm{~ns}$ & $-0.01^{*}$ & $0.02^{*}$ & $0.01^{*}$ & $4.29^{*}$ & $-1.44^{*}$ & $1.42^{*}$ & $4.17 n s$ & $3.96 \mathrm{~ns}$ & $4.07^{\star}$ \\
\hline P4XP7 & $1.29^{*}$ & $1.14^{*}$ & $1.22^{*}$ & $0.03^{*}$ & $0.03^{*}$ & $0.03^{*}$ & $-2.03^{*}$ & $1.11^{*}$ & $-0.46^{*}$ & $0.92 \mathrm{~ns}$ & $0.88 \mathrm{~ns}$ & $0.90 \mathrm{~ns}$ \\
\hline $\begin{array}{l}\text { P4XP8 } \\
\end{array}$ & $-1.81^{*}$ & $-1.63^{*}$ & $-1.72^{*}$ & $-0.02^{*}$ & $-0.04^{*}$ & $-0.03^{*}$ & $-2.26^{\star}$ & $0.33^{*}$ & $-0.96^{*}$ & $-5.09^{*}$ & $-4.84 n s$ & $-4.97^{*}$ \\
\hline P5XP6 & $-0.83 n s$ & $-0.83 n s$ & $-0.83^{*}$ & $-0.01^{*}$ & $-0.01^{*}$ & $-0.01^{*}$ & $-0.19 n s$ & $-0.18 n s$ & $-0.19 n s$ & $-6.15^{*}$ & $-5.85^{\star}$ & $-6.00^{*}$ \\
\hline P5XP7 & $0.69 \mathrm{~ns}$ & $0.49 \mathrm{~ns}$ & $0.59 \mathrm{~ns}$ & $0.02^{\star}$ & $-0.01^{*}$ & $9101^{*}$ & $2.00^{*}$ & $1.96^{*}$ & $1.98^{\star}$ & $4.34 n s$ & $4.13 \mathrm{~ns}$ & $4.23^{*}$ \\
\hline P5XP8 & $0.13 n s$ & $0.35 \mathrm{~ns}$ & $0.24 \mathrm{~ns}$ & $-0.01 n s$ & $0.01^{*}$ & $0.004 \mathrm{~ns}$ & $-1.81^{*}$ & $-1.78^{*}$ & $-1.79^{*}$ & $1.81 \mathrm{~ns}$ & $1.72 \mathrm{~ns}$ & $1.77 \mathrm{~ns}$ \\
\hline L.S.D 5\% & 0.98 & 0.99 & 0.70 & 0.006 & 0.006 & 0.004 & 0.55 & 0.32 & 0.34 & 4.89 & 5.03 & 3.59 \\
\hline
\end{tabular}


Table (7): The estimated heterosis percentages over mid parent (MP) and their significance for some physiological studied characters of the studied fifteen F1 crosses grown under normal, drought stress and their combined data

\begin{tabular}{|c|c|c|c|c|c|c|c|c|c|c|c|c|c|c|c|c|c|c|c|c|c|c|c|c|}
\hline \multirow{2}{*}{\begin{tabular}{|l|} 
Character \\
Genotype
\end{tabular}} & \multicolumn{3}{|c|}{ Flag leaf area } & \multicolumn{3}{|c|}{ Chlorophyll content } & \multicolumn{3}{|c|}{ Nitrogen content } & \multicolumn{3}{|c|}{ Potassium content } & \multicolumn{3}{|c|}{$\begin{array}{c}\text { Relative water } \\
\text { content }\end{array}$} & \multicolumn{3}{|c|}{ Water use efficiency } & \multicolumn{3}{|c|}{ Leaf rolling } & \multicolumn{3}{|c|}{ Leaf angle } \\
\hline & $\mathrm{N}$ & $S$ & $\mathrm{C}$ & $\mathrm{N}$ & $\mathrm{S}$ & $\mathrm{C}$ & $\mathrm{N}$ & $\mathrm{s}$ & $\mathrm{C}$ & $\mathrm{N}$ & $\mathrm{S}$ & $\mathrm{C}$ & $\mathrm{N}$ & $S$ & $\mathrm{C}$ & $\mathrm{N}$ & $\mathrm{S}$ & $\mathrm{C}$ & $\mathrm{N}$ & $\mathrm{s}$ & $\mathrm{C}$ & $\mathrm{N}$ & $\mathrm{S}$ & $\mathrm{C}$ \\
\hline & $14.93^{*}$ & $21.93^{*}$ & $18.20^{*}$ & $3.48 \mathrm{~ns}$ & $5.60^{*}$ & $4.48^{*}$ & $1.13 \mathrm{~ns}$ & $4.67^{*}$ & $2.44^{*}$ & $6.79^{*}$ & $16.17^{\star}$ & $10.93^{*}$ & $9.98^{*}$ & $9.98^{*}$ & $9.98^{*}$ & $49.44^{*}$ & $49.53^{\star}$ & $32.74^{*}$ & $175^{*}$ & $6.33 \mathrm{~ns}$ & $22.22 \mathrm{~ns}$ & $83.53^{*}$ & $83.41^{*}$ & $83.47^{\star}$ \\
\hline P1XP7 & $9.01^{*}$ & $15.77^{*}$ & $12.17^{*}$ & $5.25^{*}$ & $4.83^{*}$ & $5.05^{*}$ & $10.81^{*}$ & $30.67^{\star}$ & $20.34^{*}$ & $17.75^{*}$ & $20.69^{*}$ & $18.85^{*}$ & $-9.06^{*}$ & $-9.06^{*}$ & $-9.06^{*}$ & $64.44^{*}$ & $52.09^{*}$ & $56.5^{*}$ & $150^{*}$ & $-9.09 n s$ & $11.11 \mathrm{~ns}$ & $47.96^{*}$ & $47.9^{*}$ & $47.94^{*}$ \\
\hline P1XP8 & $7.03^{*}$ & $13.54^{*}$ & $10.09^{*}$ & $-8.81^{*}$ & $0.32 \mathrm{~ns}$ & $-4.64^{*}$ & $1.17 \mathrm{~ns}$ & $7.97^{\star}$ & $3.87^{\star}$ & $0.00 \mathrm{~ns}$ & $6.75^{\star}$ & $2.77^{\star}$ & $16.33^{*}$ & $16.33^{*}$ & $16.32^{\star}$ & $67.22^{*}$ & $45.23^{*}$ & $46.64^{*}$ & $550^{*}$ & $136.4^{*}$ & $188.9^{*}$ & $208.4^{*}$ & $08.3^{*}$ & $208.4^{*}$ \\
\hline P2XP6 & $21.83^{*}$ & $21.26^{*}$ & $21.54^{*}$ & $\begin{array}{l}-2.49 n s \\
\end{array}$ & $-1.10 \mathrm{~ns}$ & $-1.82 \mathrm{~ns}$ & \begin{tabular}{|l|l|}
$4.12^{*}$ \\
\end{tabular} & $8.51^{*}$ & $5.77^{\star}$ & $7.48^{*}$ & $3.04^{*}$ & $5.35^{*}$ & $-3.28^{*}$ & $-3.28^{*}$ & $-3.28^{*}$ & $39.15^{*}$ & \begin{tabular}{|l|}
$44.39^{*}$ \\
\end{tabular} & $24.68^{*}$ & $250^{*}$ & $-8.33 \mathrm{~ns}$ & $25 \mathrm{~ns}$ & $110^{*}$ & $110^{*}$ & \begin{tabular}{|l|l|}
$110^{*}$ \\
\end{tabular} \\
\hline P2XP7 & $16.40^{*}$ & $15.83^{*}$ & $16.12^{\star}$ & $-5.50^{*}$ & $-6.35^{*}$ & $-5.90^{*}$ & $2.81^{*}$ & $1.30 \mathrm{~ns}$ & $2.70^{*}$ & $0.35 \mathrm{~ns}$ & $5.86^{*}$ & $2.96^{*}$ & $1.76 \mathrm{~ns}$ & $-1.76^{*}$ & $-1.76^{*}$ & $56.08^{*}$ & \begin{tabular}{|l|l|}
$33.46^{*}$ \\
\end{tabular} & $43.29^{*}$ & 100ns & $-41.7^{\star}$ & $-25 n s$ & $119.1^{*}$ & $119.2^{\star}$ & $119.2^{*}$ \\
\hline P2XP8 & $13.74^{*}$ & $12.91^{*}$ & $13.33^{*}$ & $-9.07^{*}$ & $0.97 \mathrm{~ns}$ & $-5.35^{*}$ & $-7.93^{*}$ & $18.60^{*}$ & $4.08^{\star}$ & $-12.04^{*}$ & $-13.77^{\star}$ & -12.60 & $-9.64^{\star}$ & $-9.64^{*}$ & $-9.64^{*}$ & $47.62^{\star}$ & \begin{tabular}{|l|}
$24.48^{\star}$ \\
\end{tabular} & $25.97^{\star}$ & $400^{*}$ & $50^{*}$ & $90^{\star}$ & $183.6^{*}$ & $\left|183.7^{\star}\right|$ & $183.7^{\star}$ \\
\hline P3XP6 & $9.55^{*}$ & $9.54^{*}$ & $9.55^{*}$ & $-10.94^{*}$ & $-9.91^{*}$ & $-10.45^{*}$ & $29.14^{*}$ & $28.46^{*}$ & $28.87^{*}$ & $23.60^{*}$ & $23.66^{*}$ & $23.79^{*}$ & $3.80^{*}$ & $3.81^{*}$ & $3.81^{\star}$ & & $45.33^{*}$ & $21.46^{*}$ & $500^{*}$ & $188.9^{*}$ & & $304.6^{*}$ & & \\
\hline P3XP7 & $\frac{12.68^{*}}{1}$ & $12.69^{*}$ & $\frac{.059^{*}}{12.69^{\prime}}$ & $-3.42 \mathrm{~ns}$ & $-4.66^{*}$ & $-4.02^{*}$ & $26.42^{\star}$ & $36.36^{*}$ & $30.49^{*}$ & $27.70^{*}$ & $\frac{2.000^{*}}{27.6}$ & $27.79^{\star}$ & $0.07 \mathrm{~ns}$ & $0.07 \mathrm{~ns}$ & $0.07 \mathrm{~ns}$ & $44.5^{*}$ & $\frac{4.05}{32.38^{*}}$ & $37.19^{*}$ & $450^{*}$ & $100^{*}$ & $185.7^{\star}$ & $21.46^{*}$ & \begin{tabular}{|l|}
$20.47^{\star}$ \\
\end{tabular} & \begin{tabular}{|l|}
$20.98^{*}$ \\
\end{tabular} \\
\hline P3XP8 & $10.55^{*}$ & $10.31^{*}$ & $10.43^{*}$ & $-5.72^{\star}$ & $2.83 \mathrm{~ns}$ & $-1.79 \mathrm{~ns}$ & $16.55^{*}$ & $56.78^{*}$ & $33.08^{*}$ & $34.44^{*}$ & $34.85^{*}$ & $34.11^{*}$ & $13.06^{*}$ & $13.06^{*}$ & $13.05^{*}$ & $52.5^{*}$ & $58.92^{\star}$ & $42.56^{*}$ & $500^{*}$ & $188.9^{*}$ & $7.1^{\star}$ & $3.07 \mathrm{~ns}$ & \begin{tabular}{|l|}
$3.09 \mathrm{~ns}$ \\
\end{tabular} & $08 \mathrm{~ns}$ \\
\hline P4XP6 6 & $26.53^{*}$ & $26.93^{*}$ & $26.72^{\star}$ & $-2.41 \mathrm{~ns}$ & $-0.98 \mathrm{~ns}$ & $-1.73 \mathrm{~ns}$ & \begin{tabular}{|l|}
$3.82^{*}$ \\
\end{tabular} & $5.30^{*}$ & \begin{tabular}{|l|}
$3.42^{\star}$ \\
\end{tabular} & \begin{tabular}{|l|}
$13.89^{*}$ \\
\end{tabular} & $17.62^{\star}$ & $15.83^{*}$ & $-1.74 \mathrm{~ns}$ & $-1.73 n s$ & $-1.73^{*}$ & $37.43^{*}$ & \begin{tabular}{|l|}
$74.3^{*}$ \\
\end{tabular} & $41.7^{*}$ & $350^{*}$ & \begin{tabular}{|c|} 
Ons \\
\end{tabular} & $63.64^{*}$ & $267.2^{*}$ & \begin{tabular}{|l|}
$267.3^{*}$ \\
\end{tabular} & $267.2^{\star}$ \\
\hline P4XP7 & $21.74^{*}$ & $22.13^{*}$ & $21.92^{\star}$ & $3.63^{*}$ & $2.68 \mathrm{~ns}$ & $3.18^{*}$ & $2.42^{\star}$ & $0.00 \mathrm{~ns}$ & $0.32 \mathrm{~ns}$ & $9.64^{*}$ & $10.28^{*}$ & $10.11^{*}$ & $-11.29^{*}$ & $-11.29^{*}$ & $-11.29^{*}$ & $47.59^{*}$ & \begin{tabular}{|l|l|}
$17.97^{*}$ \\
\end{tabular} & $30.04^{*}$ & $250^{*}$ & $-38.9^{*}$ & 13.64 & $191.1^{*}$ & $191^{*}$ & \begin{tabular}{|l|}
$191^{*}$ \\
\end{tabular} \\
\hline P4XP8 & $23.27^{*}$ & $23.40^{*}$ & $23.33^{*}$ & $\begin{array}{c}-1.42 \mathrm{~ns} \\
-1\end{array}$ & $7.60^{*}$ & $2.72^{\star}$ & $9.27^{*}$ & $17.50^{*}$ & \begin{tabular}{|l|l|}
$11.68^{*}$ \\
\end{tabular} & $3.31^{*}$ & $1.23^{*}$ & $2.32^{\star}$ & $4.03^{*}$ & $4.03^{*}$ & $4.04^{*}$ & $34.76^{*}$ & \begin{tabular}{|l|}
$34.85^{*}$ \\
\end{tabular} & $\frac{29.6^{*}}{2}$ & $500^{*}$ & \begin{tabular}{|l|l|}
$44.44^{\star}$ \\
\end{tabular} & $127.3^{*}$ & $152.9^{*}$ & \begin{tabular}{|c|}
$152.8^{*}$ \\
\end{tabular} & \begin{tabular}{|l|}
$152.8^{*}$ \\
\end{tabular} \\
\hline P5XP6 & $\frac{12.69^{*}}{10}$ & $13.34^{*}$ & $13.00^{*}$ & $11.80^{*}$ & $-10.44^{*}$ & $-11.16^{*}$ & $-28.76^{*}$ & $-27.34^{*}$ & $-28.62^{\star}$ & $-21.25^{*}$ & $-25.00^{*}$ & $\frac{-22.91}{1}$ & $-13.00^{*}$ & $-13.00^{*}$ & $-12.99^{*}$ & \begin{tabular}{|l|}
$2.58 \mathrm{~ns}$ \\
\end{tabular} & \begin{tabular}{|l|}
$30.37^{*}$ \\
\end{tabular} & $11.16^{*}$ & $650^{*}$ & \begin{tabular}{|l|}
$62.5^{*}$ \\
\end{tabular} & $133.3^{*}$ & $25.82^{*}$ & \begin{tabular}{|l|}
$25.82^{*}$ \\
\end{tabular} & \begin{tabular}{|l|}
$25.82^{\star}$ \\
\end{tabular} \\
\hline P5XP7 & $8.16^{*}$ & $8.78^{*}$ & $8.46^{*}$ & $-15.45^{*}$ & $-16.25^{*}$ & $-15.84^{*}$ & $-17.39^{*}$ & $-15.60^{*}$ & $-15.79^{*}$ & $-8.58^{\star}$ & $-7.14^{*}$ & $-7.48^{*}$ & $-8.81^{*}$ & $-8.81^{*}$ & $-8.81^{*}$ & $9.87^{\star}$ & \begin{tabular}{|c|} 
\\
\end{tabular} & $2.77^{\star}$ & $600^{*}$ & $50^{*}$ & $136.4^{*}$ & $41.89^{*}$ & \begin{tabular}{|l|}
$41.88^{*}$ \\
\end{tabular} & $41.89^{\star}$ \\
\hline P5XP8 & $7.87^{\star}$ & $8.25^{*}$ & $8.06^{*}$ & $20.90^{*}$ & $13.26^{*}$ & $-17.41^{*}$ & $-12.24^{*}$ & $-0.86^{*}$ & $-6.42^{*}$ & $-13.46^{*}$ & $13.97^{*}$ & 13.82 & $4.99^{*}$ & $4.99^{*}$ & $4.99^{\star}$ & $5.15^{*}$ & $2.49 \mathrm{~ns}$ & $-2.37 n$ & $750^{*}$ & $112.5^{*}$ & $183.3^{\star}$ & $225^{*}$ & \begin{tabular}{|l|l}
$225^{*}$ \\
\end{tabular} & $225^{*}$ \\
\hline $\begin{array}{c}\text { L.S.D } \\
5 \%\end{array}$ & 0.60 & 0.54 & 0.55 & 1.36 & $1.11^{*}$ & 1.00 & 0.006 & 0.006 & 0.005 & 0.01 & 0.01 & 0.01 & 1.46 & 1.56 & 1.16 & 0.02 & 0.02 & 0.02 & $1.28^{*}$ & 1.24 & 0.91 & 2.71 & 2.88 & 2.51 \\
\hline
\end{tabular}

Table ( 8): General combining ability estimates of physiological characters (5 lines and 3 tester) parents grown under normal and drought stress and their combined data

\begin{tabular}{|c|c|c|c|c|c|c|c|c|c|c|c|c|c|c|c|c|c|c|c|c|c|c|c|c|}
\hline \multirow{2}{*}{\begin{tabular}{|l|} 
character \\
Genotype \\
\end{tabular}} & \multicolumn{3}{|c|}{$\begin{array}{c}\begin{array}{c}\text { Flag leaf } \\
\text { area }\end{array} \\
\end{array}$} & \multicolumn{3}{|c|}{$\begin{array}{c}\text { Chlorophyll } \\
\text { content }\end{array}$} & \multicolumn{3}{|c|}{$\begin{array}{c}\text { Nitrogen } \\
\text { content }\end{array}$} & \multicolumn{3}{|c|}{$\begin{array}{l}\text { Potassium } \\
\text { content }\end{array}$} & \multicolumn{3}{|c|}{$\begin{array}{l}\text { Relative water } \\
\text { content }\end{array}$} & \multicolumn{3}{|c|}{$\begin{array}{l}\text { Water use } \\
\text { efficiency }\end{array}$} & \multicolumn{3}{|c|}{ Leaf rolling } & \multicolumn{3}{|c|}{ Leaf angle } \\
\hline & $\mathrm{N}$ & $S$ & C & $\mathrm{N}$ & $S$ & C & $\mathrm{N}$ & $S$ & $C$ & $\mathrm{~N}$ & $S$ & $C$ & $\mathrm{~N}$ & $\mathrm{~S}$ & $\mathrm{C}$ & $\mathrm{N}$ & $S$ & $C$ & $\mathrm{~N}$ & $\mathrm{~S}$ & $C$ & $\mathrm{~N}$ & $\mathrm{~S}$ & $C$ \\
\hline P1 & $1.05^{*}$ & $0.98^{*}$ & $1.02^{*}$ & $1.97^{\star}$ & $1.82^{*}$ & $1.89^{*}$ & $0.05^{\star}$ & $0.05^{\star}$ & $0.05^{\star}$ & $0.05^{\star}$ & $0.07^{\star}$ & $0.06^{*}$ & $4.17^{\star}$ & $4.87^{\star}$ & $4.52^{\star}$ & $0.04^{\star}$ & $0.08^{*}$ & $0.06^{*}$ & $-1.20^{*}$ & $-0.95^{*}$ & $-1.08^{*}$ & $-9.96^{*}$ & $-9.43^{*}$ & $-9.69^{*}$ \\
\hline $\mathrm{P} 2$ & $2.16^{*}$ & $2.02^{*}$ & $2.09^{*}$ & \begin{tabular}{|l|l}
$1.56^{*}$ \\
\end{tabular} & $1.44^{*}$ & $1.50^{*}$ & $0.01^{*}$ & $0.01^{*}$ & $0.01^{*}$ & $\mid-0.05^{*}$ & $-0.04^{*}$ & $-0.05^{*}$ & $-2.86^{*}$ & $-3.3^{*}$ & $-3.1^{*}$ & $0.02^{*}$ & $-0.01^{*}$ & $0.01^{*}$ & & & & & 17. & \\
\hline P3 & $\mid-2.0^{*}$ & \begin{tabular}{|l|}
$-1.8^{*}$ \\
\end{tabular} & $-1.9^{*}$ & $-1.0^{*}$ & $-0.9^{*}$ & $-0.9^{*}$ & \begin{tabular}{|l|}
$0.05^{*}$ \\
\end{tabular} & $0.08^{*}$ & $0.07^{\star}$ & $0.14^{*}$ & $0.12^{*}$ & $0.13^{*}$ & $5.90^{*}$ & $6.89^{\star}$ & $6.39^{\star}$ & $0.03^{*}$ & $0.07^{*}$ & $0.05^{\star}$ & & & $0.84^{*}$ & & & \\
\hline P4 & $2.23^{*}$ & $2.08^{*}$ & $2.16^{*}$ & $2.89^{*}$ & $2.67^{\star}$ & $2.78^{*}$ & $-0.03^{*}$ & $-0.03^{*}$ & $\mid-0.02^{*}$ & $0.02^{*}$ & $0.02^{*}$ & $0.02^{*}$ & $0.2 \mathrm{~ns}$ & $0.3 \mathrm{~ns}$ & $0.30^{*}$ & $-0.03^{*}$ & $0.02^{*}$ & $0.00^{*}$ & $-0.45^{*}$ & & & & t11.8 & 12.1 \\
\hline P5 & $-3.4^{*}$ & $-3.2^{*}$ & $-3.3^{*}$ & $-5.4^{\star}$ & $-5.0^{*}$ & $-5.2^{\star}$ & $-0.11^{*}$ & $-0.1^{*}$ & $-0.11^{*}$ & $-0.16^{*}$ & $-0.16^{*}$ & $-0.16^{*}$ & $-7.4^{\star}$ & $-8.74^{*}$ & $-8.1^{*}$ & $-0.06^{*}$ & $-0.16^{*}$ & $-0.11^{*}$ & $2.55^{\star}$ & $2.13^{*}$ & $2.34^{*}$ & $1.16^{*}$ & $1.10^{*}$ & $1.12^{*}$ \\
\hline L.S.D $5 \%$ & 0.14 & 0.13 & 0.13 & 0.32 & 0.26 & 0.24 & 0.001 & 0.001 & 0.001 & 0.003 & 0.003 & 0.002 & 0.35 & 0.37 & 0.27 & 0.003 & 0.005 & \begin{tabular}{|l|l|}
0.003 \\
\end{tabular} & 0.26 & 0.25 & $0.19^{*}$ & 0.55 & 0.59 & 0.51 \\
\hline P6 & $1.59^{*}$ & $1.49^{*}$ & $\mid 1.54^{\star}$ & $0.30^{*}$ & $0.28^{*}$ & $0.29^{*}$ & $\mid-0.01^{\star}$ & $-0.03^{*}$ & $\mid-0.02^{*}$ & $-0.04^{\star}$ & $-0.04^{*}$ & $-0.04^{*}$ & $-0.2 n s$ & $-0.30^{*}$ & $-0.2^{*}$ & $-0.04^{*}$ & $-0.02^{*}$ & $-0.03^{*}$ & $-0.27^{\star}$ & $x-0.27^{*}$ & $-0.27^{\star}$ & $10.29 *$ & * $9.78^{*}$ & 10.03 \\
\hline P7 & $-0.2^{*}$ & $-0.2^{\star}$ & $-0.2^{*}$ & $0.26^{*}$ & $0.24^{\star}$ & $0.25^{*}$ & $0.03^{*}$ & $0.03^{*}$ & $0.03^{*}$ & $0.06^{*}$ & $0.06^{*}$ & $0.06^{\star}$ & $0.01 \mathrm{~ns}$ & $0.01 \mathrm{~ns}$ & $0.01 \mathrm{~ns}$ & $0.03^{*}$ & $0.03^{*}$ & $0.03^{*}$ & & & & & & \\
\hline P8 & $-1.3^{*}$ & $-1.2^{*}$ & $-1.2^{*}$ & $-0.5^{*}$ & $-0.5^{*}$ & $-0.5^{*}$ & $-0.02^{*}$ & $-0.01^{*}$ & $-0.02^{*}$ & $-0.01^{*}$ & $-0.02^{\star}$ & $-0.02^{*}$ & $0.25 \mathrm{~ns}$ & $0.30^{*}$ & $0.27^{\star}$ & $0.01^{*}$ & $-0.01^{*}$ & $0.00 \mathrm{~ns}$ & & & $1.46^{*}$ & $3.82^{*}$ & $3.63^{*}$ & $3.72^{\star}$ \\
\hline L.S.D $5 \%$ & 0.11 & 0.10 & 0.10 & 0.25 & 0.20 & 0.18 & 0.001 & 0.001 & 0.001 & 0.003 & 0.003 & 0.0017 & \begin{tabular}{|l|}
0.42 \\
\end{tabular} & 0.26 & 0.25 & 0.42 & 0.38 & 0.29 & 0.20 & 0.20 & $\mid 0.14$ & 0.43 & 0.46 & 0.40 \\
\hline
\end{tabular}


Table (11): Specific combining ability (SCA) estimates of physiological characters for the fifteen F1 combiners grown under normal and drought stress and their combined data

\begin{tabular}{|c|c|c|c|c|c|c|c|c|c|c|c|c|c|c|c|c|c|c|c|c|c|c|c|c|}
\hline \multirow{2}{*}{\begin{tabular}{|l|} 
Character \\
Genotype
\end{tabular}} & \multicolumn{3}{|c|}{ Flag leaf area } & \multicolumn{3}{|c|}{ Chlorophyll content } & \multicolumn{3}{|c|}{ Nitrogen content } & \multicolumn{3}{|c|}{ Potassium content } & \multicolumn{3}{|c|}{$\begin{array}{c}\text { Relative water } \\
\text { content }\end{array}$} & \multicolumn{3}{|c|}{$\begin{array}{l}\text { Water use } \\
\text { efficiency }\end{array}$} & \multicolumn{3}{|c|}{ Leaf rolling } & \multicolumn{3}{|c|}{ Leaf angle } \\
\hline & $\mathrm{N}$ & $\mathrm{S}$ & $\mathrm{C}$ & $\mathrm{N}$ & $\mathrm{s}$ & $\mathrm{C}$ & $\mathrm{N}$ & $\mathrm{s}$ & $\mathrm{C}$ & $\mathrm{N}$ & $\mathrm{s}$ & $\mathrm{C}$ & $\mathrm{N}$ & $\mathrm{S}$ & $\mathrm{C}$ & $\mathrm{N}$ & $\mathrm{S}$ & $\mathrm{C}$ & $\mathrm{N}$ & $\mathrm{S}$ & $\mathrm{C}$ & $\mathrm{N}$ & $\mathrm{S}$ & $\mathrm{C}$ \\
\hline \begin{tabular}{|l|} 
P1XP6 \\
\end{tabular} & $0.69^{*}$ & $0.64^{*}$ & $0.66^{*}$ & $1.08^{*}$ & $1.00^{*}$ & $1.04^{*}$ & $-0.01^{*}$ & $-0.01^{*}$ & $-0.01^{*}$ & $-0.01^{*}$ & $0.01^{*}$ & $0.00 \mathrm{~ns}$ & $3.56^{*}$ & $4.16^{*}$ & $3.86^{*}$ & $-0.01^{*}$ & $-0.07^{*}$ & $-0.04^{*}$ & $-0.90^{*}$ & $-0.90^{*}$ & $-0.90^{*}$ & $-19.60^{*}$ & $-18.61^{\circ}$ & $-19.10^{-}$ \\
\hline P1XP7 & $-0.20 \mathrm{~ns}$ & $-0.19 \mathrm{~ns}$ & $-0.19 \mathrm{~ns}$ & $1.03^{*}$ & $0.95^{*}$ & $0.99^{*}$ & $0.02^{*}$ & $0.07^{*}$ & $0.04^{*}$ & $0.05^{*}$ & $0.02^{*}$ & $0.03^{*}$ & $-6.59^{*}$ & $-7.69^{*}$ & $-7.14^{*}$ & $-0.01^{*}$ & $0.07^{*}$ & $0.3^{*}$ & $-0.4 \mathrm{~ns}$ & $-0.05 \mathrm{~ns}$ & $-0.23 \mathrm{~ns}$ & $-6.32^{*}$ & $-5.95^{*}$ & $-6.14^{*}$ \\
\hline P1XP8 & $-0.49^{*}$ & $-0.45^{*}$ & $\mid-0.47^{*}$ & $-2.11^{*}$ & $-1.96^{*}$ & $-2.03^{*}$ & $-0.01^{\star}$ & $-0.05^{*}$ & $-0.03^{*}$ & $-0.03^{*}$ & $-0.02^{*}$ & $-0.03^{*}$ & $3.03^{*}$ & $3.53^{*}$ & $3.28^{*}$ & $0.02^{*}$ & $0.00 \mathrm{~ns}$ & $0.01^{*}$ & $1.30^{*}$ & \begin{tabular}{|c|}
$0.95^{*}$ \\
\end{tabular} & $1.13^{*}$ & $25.92^{*}$ & $24.56^{*}$ & $25.24^{*}$ \\
\hline P2XP6 & $0.64^{*}$ & $0.60^{*}$ & $0.62^{*}$ & $1.00^{*}$ & $0.92^{*}$ & $0.96^{*}$ & $0.02^{*}$ & $0.02^{*}$ & $0.02^{*}$ & $0.06^{*}$ & $0.03^{*}$ & $0.04^{*}$ & $1.18^{*}$ & $1.38^{*}$ & $1.28^{*}$ & $0.00 \mathrm{~ns}$ & $-0.02^{*}$ & $-0.01^{*}$ & $0.27 \mathrm{~ns}$ & $0.02 n s$ & $0.14 \mathrm{~ns}$ & $-6.68^{*}$ & $-6.36^{*}$ & $-6.52^{*}$ \\
\hline P2XP7 & $0.05 \mathrm{~ns}$ & $-0.05 \mathrm{~ns}$ & $-0.05 \mathrm{~ns}$ & $-0.97^{*}$ & $-0.89^{*}$ & & $0.003^{*}$ & $-0.03^{*}$ & $-0.01^{*}$ & $-0.01^{*}$ & $0.02^{*}$ & $0.00 \mathrm{~ns}$ & $6.52^{*}$ & $7.61^{*}$ & $7.06^{*}$ & $0.01^{*}$ & $0.06^{*}$ & $0.04^{*}$ & $-0.48^{*}$ & $0.12 \mathrm{~ns}$ & $-0.18 \mathrm{~ns}$ & $9.90^{*}$ & $9.42^{*}$ & $9.66^{*}$ \\
\hline P2XP8 & $-0.59^{*}$ & $-0.55^{*}$ & \begin{tabular}{|l|}
$-0.57^{*}$ \\
\end{tabular} & $-0.03 n s$ & $-0.03 \mathrm{~ns}$ & $-0.03 \mathrm{~ns}$ & $-0.03^{*}$ & $0.01^{*}$ & $-0.01^{*}$ & $-0.05^{*}$ & $-0.05^{*}$ & $-0.05^{*}$ & $\frac{-7.70^{*}}{4}$ & $-8.99^{*}$ & $-8.34^{*}$ & $-0.01^{*}$ & $-0.05^{*}$ & $-0.03^{*}$ & $0.22 \mathrm{~ns}$ & \begin{tabular}{|c|}
$-0.13 n s$ \\
\end{tabular} & $0.04 \mathrm{~ns}$ & $-3.22^{*}$ & $-3.06^{*}$ & $-3.14^{*}$ \\
\hline P3XP6 & $-1.38^{*}$ & $-1.29^{*}$ & $-1.34^{*}$ & $-2.07^{\star}$ & $-1.92^{*}$ & $-1.99^{*}$ & $0.02^{*}$ & $-0.01^{*}$ & $0.01^{*}$ & $-0.04^{*}$ & $-0.04^{*}$ & $-0.04^{*}$ & $-1.12^{*}$ & $-1.31^{*}$ & $-1.22^{\star}$ & $-0.03^{*}$ & $-0.09^{*}$ & $-0.06^{*}$ & \begin{tabular}{|l|l|}
$0.43 \mathrm{~ns}$ \\
\end{tabular} & \begin{tabular}{|l|}
$0.93^{*}$ \\
\end{tabular} & $0.68^{*}$ & \begin{tabular}{|l|l|}
$40.64^{*}$ \\
\end{tabular} & \begin{tabular}{|l|l|}
$38.60^{*}$ \\
\end{tabular} & \begin{tabular}{|l|l}
$39.62^{*}$ \\
\end{tabular} \\
\hline P3XP7 & $0.84^{*}$ & $0.78^{*}$ & $0.81^{*}$ & $0.25 \mathrm{~ns}$ & $0.23 \mathrm{~ns}$ & $0.24 \mathrm{~ns}$ & $0.003^{*}$ & $-0.002 \mathrm{~ns}$ & $-0.001 \mathrm{~ns}$ & $-0.02^{*}$ & $-0.03^{*}$ & $-0.03^{*}$ & $0.36 \mathrm{~ns}$ & $0.42 \mathrm{~ns}$ & $0.39 \mathrm{~ns}$ & $-0.01^{*}$ & $0.01 \mathrm{~ns}$ & $0.00 \mathrm{~ns}$ & $0.68^{*}$ & $0.03 \mathrm{~ns}$ & $0.36^{*}$ & $-8.96^{*}$ & $-8.63^{*}$ & \begin{tabular}{|l|l|} 
& $-8.79^{*}$ \\
\end{tabular} \\
\hline P3XP8 & $0.54^{*}$ & $0.51^{*}$ & $0.52^{*}$ & $1.83^{*}$ & $1.69^{*}$ & $1.76^{*}$ & $-0.03^{*}$ & $0.02^{*}$ & $-0.01^{*}$ & $0.07^{*}$ & $0.06^{*}$ & $0.06^{*}$ & $0.76^{*}$ & $0.89^{*}$ & $0.82^{\star}$ & \begin{tabular}{l|l|}
$0.04^{*}$ \\
\end{tabular} & $0.08^{*}$ & $0.06^{*}$ & \begin{tabular}{|l|l|}
$-1.12^{*}$ \\
\end{tabular} & $-0.97^{*}$ & $-1.04^{*}$ & $-31.69^{*}$ & $-29.97^{*}$ & -30.83 \\
\hline P4XP6 & $0.02 \mathrm{~ns}$ & $0.01 \mathrm{~ns}$ & $0.01 \mathrm{~ns}$ & $-1.33^{*}$ & $-1.23^{*}$ & $-1.28^{*}$ & $-0.001 \mathrm{~ns}$ & $0.02^{*}$ & $0.01^{*}$ & $0.03^{*}$ & $0.04^{*}$ & $0.04^{*}$ & $1.27^{*}$ & $1.49^{*}$ & $1.38^{*}$ & $0.03^{*}$ & $0.12^{*}$ & \begin{tabular}{|c|}
$0.07^{*}$ \\
\end{tabular} & $0.10 \mathrm{~ns}$ & $0.18 \mathrm{~ns}$ & $0.14 \mathrm{~ns}$ & $8.34^{*}$ & $7.91^{*}$ & $8.12^{*}$ \\
\hline P4XP7 & $-0.44^{*}$ & $-0.38^{*}$ & \begin{tabular}{|l|l|}
$-0.40^{*}$ \\
\end{tabular} & $0.41 \mathrm{~ns}$ & \begin{tabular}{|l|}
$0.38 \mathrm{~ns}$ \\
\end{tabular} & $0.40 \mathrm{~ns}$ & $-0.02^{*}$ & $-0.03^{*}$ & $-0.02^{*}$ & $-0.02^{*}$ & $-0.02^{*}$ & $-0.02^{*}$ & $-2.23^{*}$ & $-2.60^{*}$ & $-2.44^{*}$ & $0.01^{*}$ & $-0.11^{*}$ & $-0.05^{*}$ & $-0.1 \mathrm{~ns}$ & \begin{tabular}{|c|}
$-0.47^{\star}$ \\
\end{tabular} & $-0.31 \mathrm{~ns}$ & $10.40^{*}$ & $9.88^{*}$ & $10.14^{*}$ \\
\hline P4XP8 & $0.39^{*}$ & $0.37^{*}$ & $0.38^{*}$ & $0.92^{*}$ & \begin{tabular}{|l|l|}
$0.85^{*}$ \\
\end{tabular} & $0.89^{*}$ & $0.02^{*}$ & $0.01^{*}$ & $0.01^{*}$ & $-0.01^{*}$ & $-0.02^{*}$ & $-0.02^{*}$ & $0.95^{*}$ & $1.11^{*}$ & $1.03^{*}$ & $-0.04^{*}$ & $-0.01 \mathrm{~ns}$ & $-0.022^{*}$ & $0.05 \mathrm{~ns}$ & \begin{tabular}{|l|}
$0.28 \mathrm{~ns}$ \\
\end{tabular} & \begin{tabular}{|l|l|}
$0.167 \mathrm{~ns}$ \\
\end{tabular} & \begin{tabular}{|l|l|}
$-18.74^{*}$ \\
\end{tabular} & $-17.79^{*}$ & -18.26 \\
\hline P5XP6 & $0.04 \mathrm{~ns}$ & $0.04 \mathrm{~ns}$ & $0.04 \mathrm{~ns}$ & $1.32^{*}$ & $1.23^{*}$ & 1.28 & $-0.03^{*}$ & $-0.01^{*}$ & -0.03 & $-0.04^{*}$ & $-0.05^{*}$ & $-0.04^{*}$ & $-4.89^{*}$ & $-5.71^{*}$ & $-5.30^{*}$ & $\begin{array}{ll}0.02^{*} \\
\end{array}$ & $0.06^{*}$ & $0.04^{*}$ & $0.10 \mathrm{~ns}$ & \begin{tabular}{|l|}
$-0.23 \mathrm{~ns}$ \\
\end{tabular} & $-0.07 \mathrm{~ns}$ & \begin{tabular}{|l|}
$-22.70^{*}$ \\
\end{tabular} & $-21.54^{*}$ & 22.12 \\
\hline P5XP7 & $-0.17 n s$ & $-0.16 \mathrm{~ns}$ & \begin{tabular}{|c|}
$-0.17 n s$ \\
\end{tabular} & $-0.72^{*}$ & $-0.66^{\circ}$ & $-0.69^{*}$ & $-0.01^{*}$ & $-0.01^{*}$ & -0.01 & $0.01^{*}$ & $0.01^{*}$ & & $1.93^{*}$ & $2.26^{*}$ & $2.10^{*}$ & $0.00 \mathrm{~ns}$ & $-0.03^{*}$ & $-0.02^{*}$ & $0.35 \mathrm{~ns}$ & \begin{tabular}{|l|}
$0.37 \mathrm{~ns}$ \\
\end{tabular} & $0.36^{*}$ & $\left|-5.0^{*}\right|$ & $-4.72^{*}$ & $-4.87^{\star}$ \\
\hline P5XP8 & $0.14 \mathrm{~ns}$ & $0.13 \mathrm{~ns}$ & \begin{tabular}{|l|}
$0.13 n s$ \\
\end{tabular} & $-0.60^{*}$ & $-0.56^{*}$ & $-0.58^{*}$ & $0.04^{*}$ & $0.02^{*}$ & $0.03^{*}$ & $0.03^{*}$ & $0.03^{*}$ & $0.03^{*}$ & $2.96^{*}$ & $3.45^{*}$ & $3.20^{*}$ & \begin{tabular}{|c|}
$-0.02^{*}$ \\
\end{tabular} & $-0.03^{*}$ & $-0.02^{*}$ & \begin{tabular}{|l|}
$-0.4 \mathrm{~ns}$ \\
\end{tabular} & \begin{tabular}{|c|}
$-0.13 \mathrm{~ns}$ \\
\end{tabular} & \begin{tabular}{|l|}
$-0.29 \mathrm{~ns}$ \\
\end{tabular} & $27.72^{\star}$ & \begin{tabular}{|l|}
$26.26^{*}$ \\
\end{tabular} & $26.99^{*}$ \\
\hline $\begin{array}{l}\text { L.S.D } \\
5 \%\end{array}$ & 0.24 & 0.22 & 0.22 & 0.55 & 0.45 & 0.41 & 0.003 & 0.002 & 0.002 & 0.006 & 0.006 & 0.004 & 0.60 & 0.64 & 0.47 & 0.005 & 0.008 & 0.005 & 0.45 & 0.44 & 0.32 & 0.96 & 1.02 & 0.89 \\
\hline
\end{tabular}

